\title{
EL DEBATE TEOLÓGICO-POLÍTICO SOBRE EL REINO EN LA EUROPA DE ENTREGUERRAS
}

Fecha de recepción: 18 de junio de 2020

Fecha de aceptación: 30 de septiembre de 2020

RESUMEN: Aunque la cuestión teológico-política del Reino no fuese nueva en la Europa de entreguerras, los debates sobre la realización histórica del Reino y sobre el mesianismo abrieron nuevas perspectivas influidas por el auge de los totalitarismos fascista, comunista y racista, las debilidades de los Estados liberales y la resistencia católica ante los usos políticamente no ingenuos pretendidos por Action Française, por la Reichstheologie y por otros. El artículo presenta la discusión sobre aquellas posiciones y subraya la persistente ambigüedad de toda utilización teológico-política del significado del Reino y las posibilidades de un proyecto histórico de matriz cristiana consciente de su raíz judía y de la permanente reserva escatológica que previene al cristianismo ante la pretensión de considerar un sistema socioeconómico o político cualesquiera como algo definitivo. El mesianismo conforma cada vez más una instancia crítica ante un Reino realizado en la tierra.

PALABRAS CLAVE: fiesta de Cristo Rey; mesianismo; monoteísmo; nueva cristiandad; politische Theologie; Reino; théologie politique.

\footnotetext{
* Departamento de Teología Dogmática e Historia. Departamento de Humanidades y Filosofía. Universidad Loyola Andalucía: margenat@uloyola.es;

ORCID: https://orcid.org/0000-0002-2646-1804
} 


\section{The theological-political debate on the Kingdom in the interwar Europe}

ABSTRACT: Although the theological-political question of the Kingdom was not new in interwar Europe, the debates on the historical realization of the Kingdom and on messianism opened up new perspectives influenced by the rise of fascist, communist and racist totalitarianisms, the weaknesses of the States Liberals and Catholic resistance to the politically non-naive uses claimed by Action Française, the Reichstheologie and others. The article presents the discussion on those positions and highlights the persistent ambiguity of any theological-political use of the meaning of the Kingdom and the possibilities of a historical project with a Christian mould aware of its Jewish roots and of the permanent eschatological reserve that prevents Christianity from facing the claim to consider any socio-economic or political system as something definitive. Messianism increasingly forms a critical instance before a Kingdom realized on earth.

KEY WORDS: liturgical fest of Christ the King; messianism; monotheism; new Christianity; politische Theologie; Kingdom; théologie politique.

\section{INTRODUCCIÓN ${ }^{1}$}

El debate sobre el reino - y la teología propia de este concepto- no era del todo nuevo en el ambiente teológico europeo anterior a los años veinte, aunque entre las dos guerras mundiales, especialmente en Alemania y parcialmente en Francia, hubo una discusión de fondo representada sobre todo por las posiciones de Carl Schmitt y Erik Peterson. El primero ironizaba bastantes años más tarde sobre la «puntilla» indolora que en 1935 Peterson parecía haber pretendido asestar a la teología política con Der Monotheismus als politisches Problem. El teólogo Peterson, que había muerto en 1960, ya no podía defenderse.

En 1922 el concepto de teología política fue usado por el propio Schmitt en uno de sus libros más conocidos, Politische Theologie, reeditado con alguna revisión en 1933. Un año después, Jacques Maritain pronunciaba en Santander las conferencias sobre "Problemas espirituales y temporales

${ }^{1}$ Grupo de investigación Derechos humanos, tradición jesuita y transformación social de la Universidad Loyola Andalucía y Grupo de investigación DHLTS HUM973 del Sistema de Investigación Científica de Andalucía (SICA), coordinado por el profesor Eduardo Ibáñez Ruiz del Portal. El autor agradece los atinados comentarios y observaciones de los evaluadores anónimos y de la redacción de la revista, que ha intentado incorporar al texto definitivo. 
de una nueva cristiandad" ${ }^{2}$, cuyo texto daba lugar en 1936 a su ensayo más conocido y fundamental, Humanisme intégral. En él señalaba tres errores y proponía la que él consideraba solución cristiana ${ }^{3}$. En 1936, dos años más tarde, el filósofo alemán Aloïs Dempf debía haber pronunciado unas conferencias en el mismo marco, Santander y su universidad de verano. La sublevación militar de julio hizo imposibles las mismas, que en 1937 aparecieron en Salzburgo como libro, Christliche Staatsphilosophie in Spanien y, ¡40 años después!, en Madrid en traducción castellana publicada por Rialp ${ }^{4}$. Éstas, y aun otras obras, son representativas de un debate que no es ajeno ni al contexto político ni al pretendido uso político de la Reichstheologie. En los mismos años en que Schmitt publicaba la primera edición de Politische Theologie, el papa Pío XI escribía sus dos encíclicas programáticas: Ubi arcano (1922) y Quas primas (1925), instaurando con esta última la fiesta litúrgica de Cristo Rey. La teología del Reino — «le problème du Royaume de Dieu» escribe Maritain en su Humanisme intégral ${ }^{5}$ - está entre los temas teológicos de las dos décadas entre 1920 y 1940.

Por otra parte, en los mismos años, hubo una creciente e interesante reflexión, más filosófica que estrictamente teológica, sobre el mesianismo, que debemos encuadrar en el proceso de larga duración de la secularización del pensamiento judío a partir de la haskalah conocida como la ilustración judía en el siglo XVIII, y de la reacción hasídica ante la misma, bien representada en el siglo XX por G. Scholem, M. Buber o

${ }^{2}$ Con ese título, la editorial Signo publicó la primera edición en Cursos de la Universidad Internacional de verano en Santander - 2. Madrid 1935, 220 páginas y el Patronato de la Universidad Internacional de Verano de Santander (Ministerio de Instrucción Pública y Bellas Artes), Madrid 1935, publicó un resumen de las conferencias con el título: "Problemas espirituales y morales de un nuevo cristianismo" (sic). En La Universidad Internacional de Verano en Santander: resumen de sus trabajos, 1933-1934, 291-305. El título definitivo que Maritain dio a la edición en francés (Aubier, París 1936) correspondió con el de la traducción castellana de Alfredo Mendizábal: Humanismo integral. Problemas temporales y espirituales de una nueva cristiandad. Santiago de Chile: Ercilla, 1941.

3 Jacques Maritain, y Raïssa Maritain. Oeuvres complètes. Friburgo (Suiza) París: Universitaires - Saint Paul 1984, 6:405-418; Jacques Maritain. Humanisme intégral. Problèmes temporels et spirituels d'une nouvelle chrétienté. 4. ${ }^{\mathrm{a}}$ ed. París: Aubier, 2000, 107-119.

4 Aloïs Dempf. La filosofía cristiana del Estado en España. Madrid: Rialp, 1967.

5 Jacques Maritain, y Raïssa Maritain. Oeuvres complètes, 6:405. 
F. Rosenzweig. De ésta no trataré en este texto, salvo en lo que afecta a Peterson y Maritain, lo referido al Reino de Dios.

Tras los hechos del 11 de septiembre de 2001 en los Estados Unidos de Norteamérica se ha hablado de varias maneras del retorno de religión. Unos siguen refiriéndose a «la revancha de Dios», la expresión usada en 1991 por Gilles Kepel; otros dicen que nos encontramos ante el verdadero final de la era constantiniana ${ }^{6}$; y aún hay quien afirma que, si se compara el radicalismo fundamentalista con la dualitas de la teología política cristiana, ésta sale mejor valorada, aunque sea con la forma secularizada que tiende a identificar la civitas Dei con la civitas mundi en la forma de «religión política» ${ }^{7}$. El debate en Alemania entre E. Bloch y W. Benjamin ${ }^{8}$, por un lado, y la obra de C. Schmitt por otro, reflejaban la vitalidad de esta cuestión en aquellos años de entreguerras.

La metodología utilizada ha consistido en la revisión de la bibliografía que afecta a la cuestión propuesta. En la relación final, por tanto, sólo constan obras utilizadas para dicha revisión. Algunas pocas referencias, no estrictamente bibliográficas, a textos de la tradición patrística o del magisterio aparecen convenientemente citadas en nota en su momento.

Tras esta introducción, en el apartado segundo del artículo presentaré y analizaré la categoría «reino» desde un punto de vista teológico-político,

${ }^{6}$ Massimo Borghesi. Critica della teologia política. Da Agostino a Peterson: la fine dell'era constantiniana. Bolonia: Marietti, 2018.

7 Parece que la expresión «religión política» fue utilizada por primera vez en el siglo XVI en la obra de Tomasso Campanella. Universalis Philosophiae seu metaphysicarum rerum iuxta propria dogmata libri tres, 1638. Ya en 1935 el historiador austriaco Karl Polanyi analizó «la tendencia del nacionalsocialismo a producir una religión política» y en 1938 Eric Voegelin publicó en Viena el que se considera primer uso moderno de la expresión: Die politischen Religionen. Aquellos años, otros estudiosos come Luigi Sturzo, Reinohld Niebhur o Jacques Maritain, se refirieron al totalitarismo como religión política. Recientemente, Emilio Gentile usó la expresión en su artículo "Fascism as political religión". Journal of Contemporay History 25 (1990): 229-251 y más tarde en obras como Il culto del littorio. La sacralizzazione della politica nell'Italia fascista. Roma, 1993 y Le religioni della politica. Fra democrazie e totalitarismi. Roma, 2001.

8 Sobre ese diálogo amistoso, Cf. Ernst Bloch. "Recuerdos de Walter Benjamin". Minerva. Revista del círculo de Bellas Artes 17 (2011): 25-27 [original en Der Monat 18, n. 216 (1966): 16-23], también en www.circulobellasartes.com, consulta 30-XII-2020 y Luis Arizmendi. "Walter Benjamin y Ernst Bloch: La crítica a la barbarie y el nazismo desde la modernidad lúdica y el principio esperanza". En www.marxismocritico. com, consulta 30-XII-2020. 
no dogmático o escriturístico, a través de dos breves aproximaciones: un autor decimonónico, el jesuita Henri Ramière, y el papa de entreguerras, Pío XI (1922-1939). En contextos distintos, pero no tan distantes, ambos se referían a la soberanía social de Jesucristo, el primero desde una perspectiva restauracionista, el segundo para impulsar un proyecto de recristianización social. En esos mismos años, aunque desde raíces muy distantes y distintas, tuvo lugar en el mundo judío una intensa discusión filosófico-teológica sobre el mesianismo, que también se reflejó en el catolicismo centroeuropeo; a la presentación de ese tema dedicaré el tercer apartado. En el cuarto, daré cuenta del debate teológico-político sobre el monoteísmo a partir de los escritos de Carl Schmitt y Erik Peterson. En ambos, el problema del sujeto de la soberanía refleja la politización extrema de la teología que acaba conformando la Politische Theologie de Schmitt, harto diferente de la théologie politique según Maritain ${ }^{9}$, o de la despolitización teológica a partir de la afirmación escatológica de la soberanía trinitaria (Peterson). Ambos pensamientos abren perspectivas aún vigentes en el pensamiento teológico y filosófico de principio del siglo XXI. En el quinto y último apartado, presento el pensamiento de Maritain, hacia el que se orienta nuestra reflexión: la ambigüedad esencial, pero insoslayable, del mundo y de la historia como lugar de Encarnación. Las preguntas esenciales a las que responde Maritain, respuesta que hacemos nuestra, son: ¿qué consecuencias reales tiene la fe en el Reino de Dios?, ¿tiene el cristianismo una esperanza para este mundo? y, por otro lado, el cristianismo ¿espera algo de este mundo?

Hemos realizado una revisión de la literatura científica sobre este tema que nos permite ver la continuidad de un debate y las relativas novedades que van introduciendo en el mismo, tanto por las relecturas de la teología política de Schmitt como por la nueva comprensión del mesianismo y su dimensión crítica. Tras esas actualizaciones, la radical novedad y la pertinente actualidad del planteamiento de Jacques Maritain, el ideal histórico de una nueva cristiandad analógicamente comprendida, secular, pluralista y «peregrinante», se hacen más evidentes.

\footnotetext{
9 «Je me permettrai ici une courte digression pour écarter une équivoque et pour signaler que le sens allemand des mots politische Teologie est tout différent de celui des mots français théologie politique» (Jacques Maritain y Raïssa Maritain. Oeuvres complètes, 6:406; cursivas del autor).
} 


\section{EL CONCEPTO DE «REINO»COMO CATEGORÍA TEOLÓGICO- POLÍTICA}

La teología de los tres primeros siglos cristianos, «fuertemente marcada por la idea del reinado de Cristo y la expectación de una pronta parusía», fue reemplazada en el siglo IV por la teología política imperial de Eusebio de Cesarea ${ }^{10}$. A su vez, a la teología histórica eclesial de Agustín de Hipona, nuevamente escatológica, completada a petición de éste por su discípulo el hispano Paulo Orosio de Braga, ambos en el siglo V, sucedió a finales del siglo VIII y comienzos del IX otra interpretación política del reino, la que expresaba Alcuino bajo la dominación franca, maestro de Carlomagno, en una carta a éste, su discípulo, a quien llama «dulcissime David». Según Alcuino, el rey formaba parte de las tres magistraturas más elevadas que existen en el mundo, la sublimitas apostolica, la imperialis dignitas y la regalis dignitas, siendo esta última, la que corresponde a Carlomagno, la persona superior, «in qua vos Domini nostri Iesu Christi dispensatio rectorem populi Christiani disposuit» ${ }^{11}$. El rey rige al pueblo cristiano por disposición de Cristo y en ese pueblo gracias a la sabiduría del rey, también la santa Iglesia es gobernada, exaltada y conservada por el rey. Hay un camino de ida del poder regio o imperial para gobernar la Iglesia. Como muestra todo un tratamiento posterior, el tema del reino ${ }^{12}$ recorre la historia de la teología y de la filosofía política al menos hasta el siglo XVI que se cierra con el Tratado de la religión y virtudes que debe tener el príncipe cristiano para gobernar y conservar sus Estados. Contra lo que Nicolás Machiavelo y los políticos de este tiempo enseñan de Pedro de Ribadeneyra, publicado en 1595, y reaparece con fuerza en el siglo XIX, pero sólo en el mundo católico. Aunque no es éste el lugar para exponer,

${ }_{10}$ Rafael Muñoz. "La mediación del Logos preexistente a la encarnación en Eusebio de Cesarea”. Estudios Eclesiásticos 43 (1968): 381-414 ; François Heim. La Théologie de la victoire de Constantin à Théodose. París: Beauchesne, 1992; José Luis Villacañas. Teología política imperial y comunidad de salvación cristiana. Una genealogía de la división de poderes. Madrid: Trotta, 2016, 9-20.

11 Cf. PL 100, 302.

12 Traugott Koch. "Sociedad y reino de Dios". En Fe cristiana y sociedad moderna, dirigido por Franz Böckle, Franz-Xaver Kaufmann, Karl Rahner y Bernhard Welte, 28:13-79. Madrid: SM, 1989. 
ni siquiera sumariamente, el tema, conviene dejarlo apuntado ${ }^{13}$. En el siglo XIX ya no se buscaba que un rey cristiano - o un príncipe- lograse la plena recristianización social, aunque sepamos que Henri Ramière, a quien nos referimos a continuación, mantuvo interesante correspondencia de apoyo a los pretendientes carlistas al trono español, pues como otros muchos legitimistas esperaba que una «restauración» del legítimo principio monárquico, en este caso del pretendiente carlista, conllevaría una recuperación de las posibilidades del ideal de la antigua cristiandad añorada. No era muy distinta de ésta la reivindicación de Maurras, de un primer Maritain o de los que pretendían el retorno de la forma del Sacro romano imperio germánico.

\subsection{Henri Ramière: La Soberanía SOCIAL de Jesucristo}

Identificado sobre todo como el propagador del «apostolado de la oración» desde el «teologado» jesuita de Vals-près-Le Puy (en Auvernia, sur de Francia) y como el iniciador en 1861 del boletín Messager du Coeur de Jésus, Henri Ramière (1821-1884) también fue notable por su integrismo político, su catolicismo ultramontano y su legitimismo monárquico a los que aparece siempre asociado, siéndolo menos en su pretensión de afrontar la novedad de los problemas de su tiempo y hacerlo con novedad, o su labor poco conocida como editor del manuscrito, en otro tiempo atribuido a Jean Pierre de Caussade, L'Abandon à la Providence divine. Ramière no fue simplemente un retardatario, sino un teólogo convencido de que la persona ha de contribuir al proceso de divinización del mundo. El fin de la Encarnación, se puede leer en la copia de una conferencia suya tenida en Vals en 1854, es la glorificación de Cristo mismo en su humanidad como fin de primer orden, y la perfección de todo el universo, como fin en segundo orden, ambos "fines intrínsecos», mientras que la «reparación» del pecado es también un fin intrínseco, aunque accidental. La cristología de Ramière está orientada por el «más» de una perfección ontológico universal y cósmica. Sólo esta concepción puede actuar como corazón de una espiritualidad al servicio de la confianza y del compromiso activo por

13 María Ángeles Galino Carrillo. Los tratados de educación de príncipes. Madrid: CSIC, 1946; Ernst H. Kantorowicz. Los dos cuerpos del rey. Un estudio de teología política medieval. Madrid: Alianza, 1985. 
el mundo ${ }^{14}$. En la concepción expuesta por Ramière, la gloria de Cristo consiste en su reinado en todo el universo, del que cada día Cristo debe ser amor transformador y unificador en el centro, cuyo símbolo privilegiado es el sol, como escribió reiteradamente en el Messager entre 1861 y 1863. El reinado de Cristo es cósmico y tiene como objetivo su reinado social y humano. Éste es el vínculo entre el discurso teológico y el discurso político de Ramière: "la ciudad humana debe ver el reino social de Cristo» ${ }^{15}$. Hay, sin duda, en el pensamiento de Ramière un eco de Ireneo de Lyon, para quien la Encarnación seguiría incompleta si no existiese una redención histórica de la sociedad humana, un reinado social de Cristo y de los santos. Una parte de la opinión pública, como se ve por la enorme difusión que tuvieron sus escritos, acogió el mesianismo de Ramière; otra parte de la opinión pública no aceptó sus planteamientos, ni siquiera sus superiores jesuitas, quienes le prohibieron que publicase la continuación de su libro más conocido ${ }^{16}$, en el que debía exponer su pensamiento mesiánico ${ }^{17}$. En su correspondencia epistolar con el jesuita Albéric de Foresta (18181876), Ramière trataba sobre dicho mesianismo, más extremo aún en el propio de Foresta. El reino debería comenzar con la conversión de los judíos, a la que remiten los capítulos 9, 10 y 11 de la carta paulina a los Romanos, tras ella Jerusalén sería el centro de la humanidad y todos los pueblos abrazarían el cristianismo. Esta concepción en su día influyó probablemente en la imagen del «Cristo Omega» que germinó en el joven estudiante de Vals, Pierre Teilhard de Chardin (1881-1955). A la misma se opuso en su día Gaston Fessard (1897-1978). Todo ello forma parte de la «histoire secrète» de los jesuitas franceses según el historiador Pierre Vallin, de quien procede la expresión entrecomillada ${ }^{18}$.

14 Pierre Vallin. "Le Père Henri Ramière (1821-1884)". Bulletin de Littérature Ecclésiastique 86 (1985): 28.

15 Ibid.

${ }^{16}$ Henri Ramière. Las esperanzas de la Iglesia (Esperances de l'Église, 1861). Barcelona: Cristiandad, 1962. Otras obras del mismo autor que muestran su influjo hasta tiempos recientes son: La soberanía social de Jesucristo o las doctrinas de Roma acerca el liberalismo en sus relaciones con el dogma cristiano y las necesidades de las sociedades modernas. Barcelona: Subirana, 1875. La bancarrota del liberalismo y el catolicismo liberal. Barcelona: Católica, 1876. La soberanía social de Cristo. Barcelona: Cristiandad, 1951.

17 Vallin, 29.

18 Vallin, 30. 
La influencia de Ramière fue duradera, también en España. Todavía en 1962 se reeditaba en Barcelona Las esperanzas de la Iglesia, el mismo lugar donde habían aparecido sus obras póstumas que recogían artículos en el Messager, en 1875 La soberanía social de Jesucristo o las doctrinas de Roma acerca el liberalismo en sus relaciones con el dogma cristiano y las necesidades de las sociedades modernas, reditado en 1951 como La soberanía social de Cristo, y un año después, en 1876, La bancarrota del liberalismo y el catolicismo liberal.

\subsection{Pío XI: CRISTO IMPERA SOBRE ESTE MUNDO}

En las dos encíclicas primeras de Pío XI se trataba clara y ampliamente de la cuestión del reino de Cristo. La inaugural del pontificado, Ubi arcano Dei consilio ${ }^{19}$ (23 de diciembre de 1922), dedicaba al tema del reino de Cristo tres párrafos además de algunas otras alusiones («éste es el contenido de nuestra breve consigna: el reino de Cristo», n. 41); la séptima encíclica, Quas primas (11 de diciembre de 1925), está toda ella consagrada a la realeza de Cristo, como expresa desde el comienzo: «[...] no sólo exhortamos entonces [se refiere a Ubi arcano] a buscar la paz de Cristo en el reino de Cristo [...]. En el reino de Cristo, dijimos: pues estábamos persuadidos de que no hay medio más eficaz para restablecer y vigorizar la paz que procurar la restauración del reinado de Jesucristo» (Quas primas, n. 1).

En Quas primas se comienza haciendo alusión a la primera encíclica Ubi arcano ("Quas primas... Encyclicas Litteras», n. 1), y en ella, explícitamente titulada en la versión actual en la web del Vaticano ${ }^{20}$, «De festo Domini Nostri Iesu Christi Regis constituendo», se dedica la tercera y última parte del documento a la festividad de Jesucristo Rey (nn. 10-21), que se propone como reacción ante el laicismo contemporáneo (n. 12) y la apostasía de la sociedad moderna (nn. 13-15). A continuación, destacamos

19 Citaré los textos Quas primas y Ubi arcano respectivamente según la edición de: José Luis Gutiérrez García, ed. Doctrina pontificia. 2. Documentos políticos. Madrid: BAC, 1958; Federico Rodríguez, ed. Doctrina pontificia. 3. Documentos sociales. $2 .^{\text {a }}$ ed. Madrid: BAC, 1964. Los textos están disponibles en www.vatican.va [consulta, 12-8-2019]. La numeración de la edición electrónica no coincide con la de la BAC. En algún caso, que indicaré, propongo una traducción castellana propia.

${ }^{20}$ Consulta, 12-8-2019. 
cuatro afirmaciones centrales de ambos documentos sobre el reinado de Cristo $^{21}$.

Primera afirmación: el ejercicio de los derechos de Dios es necesario para el orden social. La admisión de los principios, leyes y preceptos de Cristo en la vida pública y en la vida privada es necesaria para el buen orden social, para el ejercicio eclesiástico del magisterio y para que la Iglesia puede ejercer los derechos de Dios sobre la sociedad y sobre los individuos. Este dominio se condensa (quod brevi dicimus ${ }^{22}$ ) en una breve expresión: Regnum Christi (Ubi arcano n. 41).

Segunda afirmación: la verdadera paz de Cristo no puede existir sino en el reino de Cristo. Si la suprema y universal soberanía de Dios es reconocida en el origen y ordenación de los poderes sociales, el reino de Cristo se ejerce en la mente de las personas, en las familias y en el Estado ( $U b i$ arcano n. 41) ${ }^{23}$. Por ello es patente que la verdadera paz de Cristo no puede existir sino en el reino de Cristo y para ello sólo hay un medio eficaz que no es otro que procurar la restauración del reino de Cristo, como decía el texto latino oficial de la encíclica inaugural del pontificado: «Ex his liquet nullam esse Christi pacem nisi in regno Christi; nec vero posse nos contendere efficacius ad pacem constabiliendam, quam Christi regnum instaurando $»^{24}$ (Ubi arcano, n. 42).

21 Josep Maria Margenat Peralta. El factor católico en la construcción del consenso del nuevo Estado franquista (1934-1937). Madrid: Universidad Complutense, 1991, 51-89.

${ }^{22}$ En Documentos sociales, n. 41, p. 573: «Este es el contenido de nuestra breve consigna: el reino de Cristo».

${ }^{23}$ En Documentos sociales, n. 41, 573. La traducción castellana dice: «Reina finalmente, Jesucristo, en el Estado...» (las cursivas en el original, de la misma forma que anteriormente escribe: «en la mente de cada uno de los hombres / in mentibus singulorum hominum» y "en la familia / in societate domestica»). Según el original latino de esa misma edición que acabamos de citar y el que aparece en www.vatican.va - consulta, 12-8-2019- el texto es: «regnat denique Iesus Dominus in societate civile» («nella società civile», en la versión en italiano).

${ }^{24}$ La versión italiana actualmente disponible en www.vatican.va dice: «faremo il lavoro più necessario insieme e più efficace per una stabile pacificazione». El texto latino de Quas primas, publicado en Documentos políticos, 493-494, dice en el n. 1 de la encíclica, que éste es un autorizado resumen del mismo papa de la encíclica programática, Ubi arcano de 1922: «in regno Christi, inquimus, quippe Nobis videbamur ad pacem redintegrandam stabiliendamque non posse efficacius, quam, Domini Nostri imperio instaurando, contendere». 
Tercera afirmación: la fiesta de Cristo Rey entraña un programa de recristianización social. En la encíclica Quas primas (1925), el papa introdujo en el calendario litúrgico la fiesta de Jesucristo rey, pues «para instruir al pueblo en las cosas de la fe y atraerle por medio de ellas a los íntimos goces del espíritu, las fiestas anuales de los sagrados misterios tienen mucha más eficacia que cualesquiera enseñanzas, por autorizadas que sean, del eclesiástico magisterio» (cfr. Quas primas n. 20). La misma encíclica daba razón de otras fiestas y de las ocasiones en que surgieron. Por un lado, "cuando se entibió la reverencia y culto al Santísimo Sacramento, entonces se instituyó la fiesta del Corpus Christi y se mandó celebrarla de tal modo que la solemnidad y magnificencia litúrgicas durasen por toda la octava, para atraer a los fieles a que veneraran públicamente al Señor», por otro lado, la encíclica recuerda que cuando se habían «enfriado y alejado la confianza de [la] eterna salvación» y las almas habían sido «debilitadas y abatidas por la triste y helada severidad de los jansenistas», se instituyó la festividad del Corazón de Jesús. A continuación, se propone que la fiesta de Cristo Rey cumpla un papel similar «contra la peste de nuestros tiempos, el llamado laicismo con sus errores y abominables intentos", que niega a la Iglesia «el derecho, fundado en el derecho del mismo Cristo, de enseñar al género humano, esto es, de dar leyes y de dirigir los pueblos para conducirlos a la eterna felicidad» (cfr. Quas primas n. 235), y unas líneas más adelante se esboza todo un programa de recristianización social, identificado con la palabra Reino de Cristo:

«A éstos les traerá a la memoria el pensamiento del juicio final, cuando Cristo, no tanto por haber sido arrojado de la gobernación del Estado cuanto también aun por sólo haber sido ignorado o menospreciado, vengará terriblemente todas estas injurias; pues su regia dignidad exige que la sociedad entera se ajuste a los mandamientos divinos y a los principios cristianos, ora al establecer las leyes, ora al administrar justicia, ora finalmente al formar las almas de los jóvenes en la sana doctrina y en la rectitud de costumbres». (cfr. Quas primas n. $33^{26}$ ).

Cuarta afirmación: la fiesta de Cristo Rey se instaura para condenar la apostasía social y acelerar la salvación. La encíclica piana añade, antes de concluir, que hubo quienes «imaginaron sustituir la religión de Cristo con cierta religión natural», pero también que «[...] no faltaron Estados que

${ }_{25}$ Documentos políticos, n. 12, p. 509.

26 Documentos políticos, n. 20, p. 516. 
creyeron poder pasarse sin Dios, y pusieron su religión en la impiedad y en el desprecio de Dios». En la mente del papa, la fiesta debe servir para «preparar y acelerar esta vuelta [de toda la humanidad al Salvador], [...] militar con infatigable esfuerzo bajo la bandera de Cristo Rey (y) condenar y reparar de alguna manera esta pública apostasía, producida, con tanto daño de la sociedad, por el laicismo». Ante éste hay que reaccionar como católicos «cuanto más se oprime con indigno silencio el nombre suavísimo de nuestro Redentor, en las reuniones internacionales y en los Parlamentos, tanto más alto hay que gritarlo y con mayor publicidad hay que afirmar los derechos de su real dignidad y potestad» (cfr. Quas primas n. $\left.25^{27}\right)$.

Esta teología de la realeza de Cristo, que he resumido brevemente en las anteriores afirmaciones, ha sido detenidamente estudiada ${ }^{28}$. El reinado social de Cristo representa el núcleo fundamental, si bien con variaciones, del proyecto «piano», es decir, de los dos papas, Pío XI y Pío XII, en los años centrales del siglo XX: 1922-1958, aunque con modulaciones diferentes en el papa Pacelli (al que, contraponiéndolo al proyecto de Maritain, se refiere más detenidamente ${ }^{29}$ ).

\section{EL DEBATE FILOSÓFICO-TEOLÓGICO SOBRE EL MESIANISMO}

El proyecto piano de recristianización era concebido por el papa como un proyecto mesiánico ya incoativamente realizado y por tanto internamente eficaz en la configuración del mundo. Después de la presentación de ese proyecto de recristianización social a través de la mediación del

27 Documentos políticos, n. 13, p. 511.

28 Cf. Daniele Menozzi. Chiesa cattolica e secolarizzazione. Turín: Einaudi, 1993. Id. Sacro Cuore. Un culto tra devozione interiore e restaurazione cristiana della società. Roma: Viella, 2002. Id. Chiesa e diritti umani: Legge naturale e modernità politica dalla Rivoluzione Francese ai nostri giorni. Bolonia: il Mulino, 2012. Id. I papi e il moderno. Una lettura del cattolicesimo contemporaneo (1903-2016). Brescia: Morcelliana, 2016. Id., y Renato Moro. Cattolicesimo e totalitarismo. Chiesa e cultura religiosa tra le due guerre mondiali. Italia, Francia e Spagna. Brescia: Morcellliana, 2004.

${ }^{29}$ Antonio Acerbi. La Chiesa nel tempo. Sguardi sui progetti di relazioni tra Chiesa e società civile negli ultimi cento anni, 2. ${ }^{a}$ ed. Milán: Vita e Pensiero, 1984, 141-198; Id., Chiesa e democrazia. Da Leone XIII al Vaticano II. Milán: Vita e pensiero, 1991, 199-250. 
reinado de Cristo, nos podemos adentrar en la cuestión más amplia del mesianismo. Ésta ha ocupado en el debate teológico católico un lugar relativamente limitado, casi siempre referido a la cuestión del Reino de Dios. En el pensamiento judío de esos años y en el debate católico y evangélico posterior a 1945 fue diferente. La Estrella de la Redención de Franz Rosenzweig en 1921 marcó un momento clave. Pretendemos empezar definiendo qué es mesianismo, para poder revisarlo después.

El mesianismo es un "complejo de expectativas, esperanzas y tensiones orientadas hacia una época escatológica de paz y de salvación $»^{30}$ y una guía para el proceso histórico de la humanidad, según la cual la persona sigue siendo responsable de la propia historia y de la propia existencia, aunque bajo la soberanía de un Dios que convoca a esta responsabilidad. Algunos movimientos de antropología cultural subrayan junto a los mesianismos estrictamente religiosos, la existencia de otras formas de mesianismo, unos de origen bíblico y cristiano, pero ya secularizados, otros emergentes en los pueblos sometidos colonialmente como autodefensa de la propia identidad amenazada. Algunos movimientos mesiánicos en la modernidad, como fueron el nazismo o el colectivismo marxista, reflejaban la conciencia de un grupo que supone o pretende tener una misión universal abierta al futuro y se percibe como responsable de la misma. En ese futuro se realizará plenamente el ideal de humanidad del que el grupo es portador y, como tal, verdadero intérprete y auténtico sujeto de la historia humana. Esta radical laicización mesiánica — ¿mesianicidad sin mesianismo?_- disminuye la parte de presencia de la acción eficaz divina y transforma el mesianismo en un destino soberano, abierto a la libre determinación humana, aunque no en el mismo sentido con que Derrida se sirve de esta expresión. Sin embargo, la afirmación de esta determinación y la confianza en la propia energía humana, incluso contra la hipóstasis de lo divino u otras mitologías, confiere al compromiso humano los rasgos del mito prometeico $^{31}$. Para otros autores, el de mesianismo es un concepto más difuso, aunque siempre se muestra como guía de la acción humana. Los movimientos mesiánicos en la modernidad tienen una constante: un grupo tiene conciencia de una misión universal abierta al futuro, que le

\footnotetext{
${ }^{30}$ Gianni Vattimo et alii, eds., 724.

31 Ibid.
} 
convierte en responsable de que ese futuro advenga, es decir, se realice. El ideal de humanidad se alcanza plenamente en la medida en que el mesianismo se realiza históricamente, es decir, se seculariza. Esta radical secularización contribuye a que disminuya la presencia de lo divino y de su pretendida acción, con lo que el mesianismo se transforma en un destino independiente de lo religioso que se abre a la determinación humana. La afirmación, sin embargo, de esta determinación, la confianza en la propia energía, incluso la contrarreferencia explícita a lo divino y a las mitologías que lo trasuntan, confiere al compromiso humano los rasgos del mito prometeico. El mesianismo «secularizado» mantiene, pues, ordinariamente la huella reconocible de su origen religioso.

Aunque nos hayamos limitado a anotar la existencia del que he llamado mesianismo secularizado, nos detendremos ahora en el mesianismo religioso. Desde la perspectiva religiosa, el mesianismo es uno de los temas más difíciles para la teología fundamental ${ }^{32}$, como también para la filosofía «secular», ésta ciertamente muy influida por los debates intrajudíos. Lo cierto es que la fe en el Mesías sirve a la teología fundamental para que ésta pueda estudiar dicha fe, tanto en el plano religioso como en el simplemente cultural, «en nombre de una esperanza común de justicia y liberación ${ }^{33}$. Cada día parece más central el estudio del mesianismo para entender la discusión filosófica de entreguerras, así como la actual.

La relación entre el tiempo y el ser recorre toda la historia de la filosofía. ¿Qué relaciones ha habido entre la temporalidad vivida y el tiempo histórico «reflexionado»? La distinción entre tiempo escatológico, tiempo teleológico y tiempo interrumpido, así como las categorías «esperanza/ nostalgia», «paciencia/olvido», «memoria/justicia» como resultado, modos y dimensiones del tiempo humano ${ }^{34}$.

La manifestación al final de tiempos de un juez y príncipe ideal, justo, habitado por el santo temor de Dios, fuerte y sabio, fue anunciada por los profetas (Is 11,1-9). Sin embargo, para los cristianos la esperanza mesiánica está «subordinada al tema mucho más fundamental del reino

\footnotetext{
${ }^{32}$ Rino Fisichella. "Mesianismo. II. Realización mesiánica”. En Diccionario de Teología Fundamental. Madrid: San Pablo, 2010, 98.

${ }^{33}$ Rino Fisichella. art. cit.

${ }^{34}$ Gérard Bensussan. Le temps messianique. Temps historique et temps vécu. $\mathrm{Pa}-$ rís: Vrin, 2001.
} 
de Dios» ${ }^{35}$. Para unos «la redención sólo puede darse cuando ya no haya historia ${ }^{36}$. ¿Agota esta afirmación la diferencia que establecieron a propósito de la intelección escatológica Bloch (futurum) y Moltmann (adventus)? Así lo escribió también Th. Adorno: «El único modo que aún le queda a la filosofía de responsabilizarse a la vista de la desesperación es intentar ver las cosas tal como aparecen desde la perspectiva de la redención ${ }^{37}$.

De manera más simbólica, «enigmática» según Rosàs ${ }^{38}$, escribió W. Benjamin: «El orden de lo profano tiene que enderezarse por su parte hacia la idea de felicidad, y la relación de este orden con lo mesiánico es uno de los elementos esenciales de la filosofía de la historia. Con ello, da lugar a una concepción mística de la historia $[\ldots]{ }^{39}$. Para el autor alemán que se suicidó en Portbou en 1940 antes de caer en manos de la policía francesa y muy probablemente ser entregado a la alemana, la búsqueda de la felicidad desde la dýnamis profana se aleja de la felicidad mesiánica, pero paradójicamente los contrarios pueden promoverse conjuntamente, así que el poder profano puede promover o apremiar silenciosamente la llegada del Reino mesiánico, aunque también puede «frenarlo». Coexisten, incluso podríamos decir co-dependen, dos restituciones, la restitutio in integrum religiosa con la restitutio in integrum mundana, en la que lo efímero natural «en su totalidad», espacial y temporal, es dirigido hacia el inapelable cumplimiento final intrahistórico.

Después de la primera gran guerra, se produjo una revitalización del pensamiento mesiánico, protagonizada sobre todo por Rosenzweig, que significó el renacimiento del pensamiento judío en el siglo XX, que, según Manuel R. Mate, a quien seguimos en estas páginas, es sin más «el renacimiento de la filosofía en Occidente ${ }^{40}$. Rosenzweig introdujo «vericuetos insospechados que desvelarán a la postre las claves profundas de

${ }^{35}$ G. Rochais. "Mesianismo. I. Espera mesiánica”. En Diccionario de Teología Fundamental. Madrid: San Pablo, 2010, 894.

${ }^{36}$ Mar Rosàs Tosas. Mesianismo en la filosofía contemporánea. De Benjamin a Derrida. Barcelona: Herder, 2016, 49. Cursivas de la autora.

37 Theodor W. Adorno. Minima Moralia. Madrid: Taurus, 1987, 250, citado por Mar Rosàs Tosas, 49.

38 Mar Rosàs Tosas, 48.

39 Walter Benjamin, Walter. Obras. II-1, Madrid: Abada, 2007, 207.

40 Manuel R. Mate. "El subsuelo teológico del nacionalismo". En El desafío nacionalista, Daniel Barreto, IX. Barcelona: Anthropos, 2018. 
un fenómeno cuya fuerza no se explica diciendo que es un sentimiento», pues en él hay sólidas opciones teóricas «tanto más eficaces cuanto menos conocidas son ${ }^{41}$. Rosenzweig representa una mirada específica de un judío sobre la modernidad, un judío que hizo una lectura de la modernidad distinta de la que pudiera hacer un cristiano o un postcristiano. «El papel de testigo de lo absoluto que ejerce el judío, con su mera existencia, es una protesta permanente contra el poder de la historia que el cristianismo nunca ha querido entender, siendo más bien la causa fundamental del anti-judaísmo del cristianismo». Lo que para el judaísmo es «vida», para el cristianismo es "vía»" Recuerda Reyes Mate que Rosenzweig en las últimas páginas de La estrella de la redención escribe: «la existencia del judío impone en todos los tiempos al cristianismo el pensamiento de que no ha llegado a la meta, de que no ha llegado a la verdad, sino que siempre sigue estando de camino. Éste es el motivo de odio más hondo del cristiano al judío, que ha recogido la herencia del odio pagano. En última instancia no es más que el odio a sí mismo, pero dirigido sobre todo al contumaz amonestador silencioso, que solo advierte, sin embargo, con su existencia [...]. El judío, sin quererlo, avergüenza al cristiano. Es odio contra la propia imperfección, contra el propio todavía no» ${ }^{43}$.

El cristiano tiene empeño en pensar que ya ha llegado, pero, concluye $R$. Mate, «la verdad es que sigue en camino. No le gusta que se lo recuerden, por eso devuelve con antisemitismo el favor que le hace el judío al recordarle dónde se encuentra $»^{44}$. El cristiano no puede renunciar al judío so pena de descarrilar en su proyecto histórico. Ésa es su «tragedia». Si identificara su ideal con alguna estación de paso, descarrilaría. El cristiano debe renunciar a «enraizar su fe en una realidad nacional», es decir, «no puede reducir el contenido de su fe a un momento de la historia. Que el punto de vista del judío cause desazón o indignación en el cristiano es harto comprensible dado que cuestiona la autoridad de la autonomía que el moderno piensa haber conquistado» ${ }^{45}$. El cristiano, al tratar de convertir el mundo, «corre el peligro de tomar una etapa por la meta. [...] Para escapar a ese peligro necesita vitalmente apoyarse en la existencia

\footnotetext{
${ }^{41}$ Mate, VII.

42 Mate, IX.

${ }^{43}$ Franz Rosenzweig. La estrella de la redención. 2. ${ }^{\mathrm{a}}$ ed. Salamanca: Sígueme, 2006, 483. Cursivas en el original.

${ }^{44}$ Mate, XII.

45 Ibid.
} 
física del pueblo judío. El Dios cristiano tiene sus raíces en el Dios de Israel. Jesús era judío» ${ }^{46}$. La subsistencia del pueblo judío como tal es «la señal de que el cristiano está por el buen camino, es decir, en camino ${ }^{47}$.

Los judíos ayudan a los cristianos, y a los demás, a interpretar fecundamente el monoteísmo a través de dos modelos: nacionalismo y cosmopolitismo. Si partimos de que la Primera Guerra Mundial fue «un choque de nacionalismos» de pueblos elegidos (cursivas mías), habrá que volver a interpretar qué significa ser pueblo elegido. "Consiste ni más ni menos que en vivir escatológicamente, es decir, anticipando el final, pendientes de la utopía de la redención ${ }^{48}$. Esta forma de vida que cada generación rehace y se apropia, se vive litúrgicamente, organizando la convivencia a partir de ritos y cultos. El pueblo judío es el pueblo que conocemos, porque es el único que plantea así su existencia. Los otros pueblos transitan «la historia luchando por hacerse con las riendas» y ponen en el devenir de los acontecimientos su expectativa de felicidad. Para los judíos, la existencia litúrgica es «un débil parapeto frente al imparable proceso de secularización de occidente». Cristianismo y judaísmo son complementarios, por lo que «una historia con matriz cristiana, como es la occidental, está condenada al fracaso si pierde de vista la interpelación judía. [...] Lo que ha ocurrido en Europa a lo largo del siglo XX —según Reyes Mate- no es un accidente sino la realización de latencias ocultas en su forma de entenderse» ${ }^{49}$. La teología de la Encarnación abrió el camino a la secularización por el que se producía una permuta: si lo absoluto entraba en la historia, ésta se cargaba de divinidad, el mundo es lo divino que ha pasado a ser secular, la eternidad que se ha hecho temporal. Al dejar de ser atemporal, la eternidad que es negación del tiempo, y hacerse temporal, la tierra pasaba a ser «el lugar de la justicia o de la esperanza». Gracias a la teología de la Encarnación lo eterno deviene acontecimiento, de manera que el Estado moderno, el Estado racional, podrá llevar a «su madurez las diversas tentativas de fundar en la tierra un pueblo de Dios» ${ }^{50}$.

La relación intrínseca entre nacionalismo y sacralidad es tan persistente porque se basa en un tipo de racionalidad, no en simples sentimientos. «Die

\footnotetext{
46 Mate, XIII.

47 Ibid. Cursivas del autor.

48 Mate, XV.

49 Mate, XVI.

50 Mate, XX.
} 
Weltgeschichte ist das Weltgericht» (la historia universal es el tribunal del mundo) afirmaba Hegel, para quien la historia aparecía como el tribunal superior de la razón, el único tribunal que puede juzgar al Estado. Algo sólo es real, verdadero y fáctico, en la medida en que llega a ser («das Wesen ist das Gewesene»). Sólo vale lo que ha llegado a ser, lo que se ha quedado por el camino de nada vale. De ahí Hegel concluye que las víctimas de la historia quedan justificadas por el éxito conseguido al final. Esta «lógica» explica la complicidad entre razón moderna y violencia: el terror está en el corazón mismo de la ilustración, de una racionalidad histórica insuperable, la encarnada por la revolución francesa. A esta razón está sometido todo ciudadano. No es difícil entender, a partir de estas premisas que, si la razón histórica no respeta la soberanía del individuo, el terror está servido, "cualquier proyecto emancipador abstracto, que haga abstracción del sufrimiento y de la libertad de los individuos, está llamado a reproducir las cadenas y el dolor que trata de superar ${ }^{51}$. Ése es el gran fracaso que señala Rosenzweig en su crítica a Hegel y el Estado ${ }^{52}$. Para el pensador judío el problema es el Estado sin más, el nacionalismo y el patriotismo.

El protestantismo, según Rosenzweig, puso a la Iglesia al servicio del Estado, es decir del «espíritu del mundo" (Weltgeist) germánico y protestante, de donde nació la incondicionalidad exigible de obediencia al Estado. Max Weber simplemente constató el fracaso ilustrado, pues los dioses, expulsados por la puerta, se habían colado por la ventana, el desencantamiento había fracasado y mutado en forma de reencantamiento, la racionalidad instrumental había triunfado, conviviendo con el politeísmo de los valores, en un mundo invadido por multitud de dioses, mientras la racionalidad de los fines naufragaba. Max Weber decía que el cristianismo era un universo totalmente distinto al judío. A diferencia suya, Rosenzweig creía que la matriz religiosa del cristianismo era la misma matriz judía y pensaba que la modernidad, que había sido pensada al margen del judaísmo, podría recuperarse si se recuperaba la conciencia judía. «La espera infructuosa de la parusía fue vivida por la comunidad de cristianos como un fracaso que obligaba a pensar de nuevo y de otra forma el tiempo. [...] La espera de [...] la realización de la promesa mesiánica

51 Ibid.

52 Mate, XXII. 
de una paz y justicia para todos [...] no tuvo respuesta $»^{53}$. Según Mate, el tiempo apocalíptico fue sustituido por un tiempo gnóstico, en el que el «progreso» funciona como «marca blanca» del gnosticismo ${ }^{54}$.

El tiempo apocalíptico tiene un fin, el tiempo gnóstico es inagotable, el apocalíptico mesiánico habla de justicia aquí y ahora, el gnóstico aplaza y desplaza; el tiempo apocalíptico vive pendiente del final reconciliado que se empeña en anticipar con propuestas políticas fraternales, mientras que el gnóstico alarga el presente indefinidamente porque teme el final catastrófico.

Una concepción de la historia que tuviera en cuenta camino y vida, las dos formas de revelación judía y cristiana que hemos apuntado, concebiría un proceso con desarrollo y final. La historia sería el proceso, el espacio de tiempo «que va de la pregunta por el sufrimiento -Adán-a su respuesta redentora - Cristo- ${ }^{55}$. La historia, para una concepción mesiánica judía como la de W. Benjamin, no debe considerarse como «aceleración» del tiempo, sino como su interrupción. En la visión simbólica del pueblo judío, según Rosenzweig, la tierra siempre es promesa, por lo que el pueblo judío siempre es «un residente provisional en su propio país ${ }^{56}$, un pueblo que no es representante -Vorstellung- de Dios, sino encarnación -Vertretung - de Dios, un pueblo que convirtió su exilio, la diáspora, en una forma de existencia, pues como defendió Lévinas ser judío consistía en reivindicar el derecho a juzgar la historia. Su juicio sobre ésta adquiere sentido para el cristiano que espera el retorno del Salvador, que «espera la Parusía ${ }^{57}$.

Según Manuel R. Mate, Rosenzweig pone de manifiesto la existencia del «subsuelo teológico del nacionalismo». La obligación de repensar todo a la luz de lo que hicimos y no supimos pensar (el «deber de memoria») orienta la posible lectura anamnética que realiza Rosenzweig, lo que nos lleva a suscribir el discurso teológico-político del filósofo judío para quien la puerta del nacionalismo facilita el paso no sólo al antisemitismo, sino a algo catastrófico para toda la humanidad ${ }^{58}$. El «trasfondo teológico,

53 Mate, XXVI.

54 Ibid.

55 Mate, XXV.

56 Mate, XXVII.

57 Emmanuel Lévinas. Difícil libertad y otros ensayos sobre judaísmo. 2. ${ }^{a}$ ed. Buenos Aires: Lilmod-Fineo, 2008.

58 Mate, XXXI. 
nunca explicitado, del nacionalismo» es el que nos permite entender el porqué de su persistencia ${ }^{59}$.

\subsection{Dos FORMAS DE MESIANISMO EN LA FILOSOFÍA CONTEMPORÁNEA}

El mesianismo, junto al reino, son las dos grandes cuestiones de la filosofía de entreguerras intrínsecamente relacionadas. Mar Rosàs plantea las tres preguntas previas que hay que responder si se quiere abordar la cuestión con claridad: qué hace el mesías, dónde y cuándo actúa ${ }^{60}$. Tras la destrucción del segundo templo en el año 70 de nuestra era, la primera cuestión —qué hace el mesías - diferenció al judaísmo del cristianismo, como sigue diferenciando las propuestas mesiánicas del siglo $\mathrm{XX}$, como veremos a continuación. La segunda respuesta es más nítida, pues mientras que para el judaísmo se trata de una redención pública y externa, la transformación de toda la sociedad, de todo el pueblo; para el cristianismo la redención acaece en el alma, de forma interior y lleva a la transformación de cada persona. La interpretación «luriana» de la historia, según G. Scholem, es performativa, es un factor $e n^{61}$ la historia. Según Isaac Luria, Dios se contrajo para crear el mundo (tsimtsum) y se rompió o exilió para repararlo o redimirlo.

El historiador contemporáneo Moshe Idel afirma que el fundamento de toda conciencia mesiánica es místico ${ }^{62}$. Tras diecisiete siglos, Idel parece dar la razón a los cristianos, frente a lo que los judíos venían afirmando - el mesianismo como algo político-nacional- hoy habría que reconocer que el mesianismo es algo místico y personal. A mediados del siglo XVIII, el hasidismo planteó el tema central del lugar de la redención. ¿Dónde se encuentra ésta?, ¿en la percepción subjetiva de la realidad o en su cambio objetivo? A la última pregunta (¿cuándo?) se puede responder de dos maneras: el mesías está por venir, es el significante de lo que está por venir, o ya ha llegado la redención en Cristo, en quien acontece la plenitud de los tiempos (Gál 4,4).

\footnotetext{
59 Ibid.

60 Mar Rosàs Tosas, 30-40.

61 La cursiva es de Mar Rosàs Tosas, 33.

62 Moshe Idel. Mesianismo y misticismo. Barcelona: Riopiedras, 1994.
} 
Esto mismo fue subrayado por Bultmann que pretendía desmitologizar la escatología, reduciéndola a la conversión existencial y por ello planteó que la decisión se toma ahora, aunque será manifiesta sólo en el juicio final. Ahora hay finalización, pero no conclusión. Lo que venga después ya no puede presentarse como una «superación de lo anterior». No habrá novedad alguna. La revelación ocurrida en la historia particular es como origen, promesa, cumplimiento (hodie, ecce), consumación ${ }^{63}$. En Cristo hubo dos venidas, dos epifanías, aunque sólo una parusía. Dicho de otra forma, desde la llegada de Jesús la redención está en marcha, pero no acontecerá del todo hasta el final de los tiempos.

El papel de la Ley en su relación con el tiempo ha sido objeto de estudio de la tradición judía (Benjamin, Buber, Scholem, Bloch, Rosenzweig, Lévinas) y desde la reflexión paulina no confesional (Badiou, Agamben, Žižek), en la que aunque judío incluimos a Taubes ${ }^{64}$ y aunque cristiano hacemos lo propio con Barth, según Mar Rosàs a quien seguimos en este aspecto en su estudio sobre el mesianismo ${ }^{65}$.

Según Rosàs, existen dos formas de mesianismo, uno anti-nómico y otro pro-nómico ${ }^{66}$. Para el primero, el mesianismo anti-nómico, la ley es la enemiga de la redención que sólo adviene desde la «radical trascendencia de Dios» (Benjamin, Barth), es decir, de la radical ilegitimidad de la ley de este mundo. Para el mesianismo antinómico sólo cabe pensar la redención desde la destrucción de este mundo caído, de este «impuesto orden desordenado». W. Benjamin se refiere a la desarticulación del tiempo y a la diferencia entre tiempo mesiánico y tiempo histórico, la ontología-del-aún-no y el tiempo del ahora. Tanto Benjamin como Karl Barth, quien afirmaba la radical «trascendencia de Dios», se enfrentan a la ley de este mundo y afirman que sólo hay redención desde la destrucción de este mundo caído. La afirmación de un mesianismo anti-nómico puede concluir fácilmente en una visión gnóstica que contrapone mundo

${ }^{63}$ Heinrich Fries. "La revelación. Las dos formas de revelación a la luz de la sagrada escritura”. En Mysterium Salutis. Manual de Teología como historia de la Salvación, dirigida por Johannes Feiner, y Magnus Löhrer. Madrid, Cristiandad, 1974, $1: 258$.

${ }^{64}$ Cf. Alfonso Galindo Hervás. "Secularización y mesianismo. El pensamiento político de Jacob Taubes”. Diánoia 57 (2012): 81-111. Cf. Jakob Taubes. La teología política de Pablo. Madrid: Trotta, 2007.

65 Mar Rosàs Tosas. Mesianismo en la filosofía contemporánea.

66 Mar Rosàs Tosas, 180-244. 
material a mundo espiritual, confiando la salvación sólo a éste último. La disyuntiva está, según Walter Benjamin, entre retrasar o acelerar el final: «Pues la naturaleza es sin duda mesiánica desde su condición efímera, eterna y total. // Perseguir esta condición efímera [...] es tarea de esa política mundial cuyo método ha de recibir el nombre de nihilismo ${ }^{67}$. El mesianismo pro-nómico es, de manera diferente, partidario de integrar la ley como medio para la redención y establece una relación directa entre ley, justicia y amor. "Algo» en el mundo mantiene la marca de lo divino, según Rosenzweig y Lévinas, y por tanto cabe reparar-el-mundo. Para el mesianismo pro-nómico la ley sirve para salir de este mundo y para Lévinas y el mesianismo antinómico en general, la ley sirve para destruir el modo del ser del mundo, pero ambos quieren reparar este mundo.

\section{EL DEBATE TEOLÓGICO-POLÍTICO SOBRE EL MONOTEÍSMO}

\subsection{CaRl Schmitt: el PRoblema del SUJeto DE LA SOberanía}

En el mundo católico alemán de los años veinte y treinta, del que estamos dando cuenta, discurría en paralelo a la cuestión del mesianismo, otro debate del que es representativo el habido entre Schmitt y Peterson que marcó una primera etapa de la teología política europea ${ }^{68}$. Es cierto que Benito Espinosa había usado esta expresión en su Tractatus theologico-politicus (1670), pero al parecer en ningún otro escrito suyo. El título del libro de Carl Schmitt («el nuevo Hobbes» según Gómez Orfanel ${ }^{69}$ ) desde su primera edición en 1922 otorgó carta de ciudadanía intelectual a la expresión teología política ${ }^{70}$. Schmitt pretendió, como jurista, utilizar los conceptos teológicos para exponer radicalmente su filosofía política. Como otros muchos pensadores alemanes de su tiempo, tampoco Schmitt

\footnotetext{
${ }^{67}$ Benjamin, 207.

68 Denis Sureau. Una nueva teología política. (En torno a la "Radical Orthodoxy"). Granada: Nuevo Inicio, 2010, 28-32.

${ }^{69}$ Germán Gómez Orfanel. "Carl Schmitt y el decisionismo político”. En Historia de la teoría política, coordinado por Fernando Vallespín. Vol. 5. Madrid: Alianza, 1995, 243.

${ }^{70}$ Sobre el origen de la expresión en Mazzini y en Bakunin, de los que pudo tomarla Schmitt, cf. Valerio D’Angelo “ «Ni dieux ni maître». Anarquismo y teología política”. Res Publica. Revista de Historia de las Ideas Políticas 22 (2019): 123-140.
} 
aceptó la derrota ante Francia en 1918 ni sus consecuencias, los tratados de 1919 o la institucionalización republicana de Alemania en 1919, conocida como República de Weimar. En 1923, un año después de su Teología política, publicó un trabajo "atípico» ${ }^{71}$ sobre la organización política de la Iglesia católica, Römischer Katholizismus und politische Form, como referente a tener en cuenta por la entonces naciente república de Weimar.

Años después, en 1969 Schmitt negó el final de la teología política, llamando «leyenda» a la posición de Erik Peterson en 1935: «va siendo hora de enfrentarse a las leyendas $»^{72}$. No deja de sorprender el comienzo del comentario que Villacañas añade a la nueva edición en castellano de la Teología política. "Quizá se pueda hacer la historia del siglo XX alrededor del complejo asunto sobre el que este libro trata» a lo que añade que el libro de Schmitt es «un documento central de la vida intelectual de la sociedad europea» ${ }^{73}$. Como es bien sabido, Schmitt aprovechó un homenaje ofrecido en 1969 al jurista católico Barion para atacar entonces a Peterson, «su amigo católico» ${ }^{74}$, que había fallecido en 1960. Schmitt, «un observador del flujo subterráneo de las corrientes espirituales», pone de manifiesto las relaciones ocultas y redescubiertas entre Barion, Peterson, Kierkegaard, Haecker y Newman ${ }^{75}$.

En su ensayo Die Kirche de 1929, Peterson ${ }^{76}$ dio el paso del dogma al sacramento, por lo que se comprende que para él el derecho sea constitutivo del catolicismo. No hay teología sin Iglesia. La dimensión escatológica de la Iglesia deriva del fracaso del reino de Cristo, a consecuencia de que los judíos han desconocido y rechazado al Mesías. Habrá Iglesia «mientras los judíos no se conviertan, mientras judíos y cristianos no tenga un Mesías común» ${ }^{77}$, pues «sólo ante el rechazo de los judíos, los Doce recibieron la inspiración de dirigirse a los gentiles ${ }^{78}$.

«Este momento fundacional de la Iglesia con la decisión de abandonar temporalmente el Reino, constituye el núcleo básico de toda

${ }^{71}$ Gómez Orfanel, 246.

72 Carl Schmitt. Teología política. Madrid: Trotta, 2009, 65.

73 José Luis Villacañas. "La leyenda de la liquidación de la teología política". En Carl Schmitt, 135.

74 Villacañas, 143.

75 Villacañas, 144.

76 Villacañas, Op.cit. 146.

77 Ibid.

78 Ibid. 
secularización posterior ${ }^{79}$, el cambio de lo escatológico - liberación, Reino, actuación mesiánica del pueblo elegido— por las postrimerías como liberación o «moralización» del alma, de la persona. La introducción de la moralización suponía una mundanización, es decir, una apuesta por la duración. Pentecostés, el momento del paso del hebreo, como lengua sagrada, a la koiné para comunicar la palabra a los gentiles, es el momento clave en que aparece la Iglesia que Jesús no fundó. El Señor predicó el Reino a los judíos, no la revelación a los gentiles, eligió a los «doce», un número simbólico de las tribus de Israel, no instituyó una jerarquía, aunque aquellos «doce» se convirtieron en apóstoles y fundaron la Iglesia. Así, la delegación jurídica de los doce, recibida para el Reino, se convirtió en capacidad para la ordenación de la Iglesia, que mostraba así su doble legitimidad como Iglesia visible, una legitimidad jurídica directa recibida de Cristo y una legitimidad pneumática recibida del Espíritu Santo. La ambigüedad es constitutiva de ese deslizamiento del Reino hacia la Iglesia. Así como Max Weber entiende la esencia de la Iglesia como la conciliación de derecho y carisma, para Peterson, «la Iglesia está más cerca de formaciones políticas, como el Reino y la polis, que de ligas libres y asociaciones ${ }^{80}$. La transformación del Reino en Iglesia - y de la escatología en postrimería - constituye el paso que más adelante despreciaron los gnósticos, quienes se concentraron en la identidad entre el tiempo del cosmos y el tiempo de la vida, por lo que prefirieron una escatología particular de naturaleza sectaria, una fuga continua del mundo y de su emancipación.

En Peterson y Schmitt, que había publicado Römischer Katholizismus und politische Form, en 1923, seis años antes de Die Kirche de Peterson, se da una forma de trasferencia diferente y paralela. En el segundo, de la Iglesia como forma del catolicismo romano a la forma política. De ahí que Karl Löwith escribiese que «ante católicos, como en el caso de mi amigo Erik Peterson, Schmitt teñía sus ideas sobre el Estado con un baño de autoridad católica» ${ }^{81}$. El jurista Schmitt tenía interés en «trasferir la

79 Ibid.

${ }^{80}$ Erik Peterson. "La Iglesia”. En Tratados teológicos, 200. Madrid: Cristiandad, 1966, citado por Villacañas, 148. En la cita que hace Villacañas, Reino parece con mayúscula y polis en cursiva, mientras en el texto de 1966 reino aparece con minúscula y polis con letras del alfabeto griego.

${ }^{81}$ Karl Löwith. Mi vida en Alemania antes y después de 1933. Un testimonio. Madrid: La Balsa de la Medusa, 1993, 111, citado por Villacañas, 149. 
forma política y jurídica de la Iglesia al Estado», a diferencia del teólogo Peterson cuyo interés era mantener la visibilidad de la Iglesia ${ }^{82}$. «Uno hablaba claramente en favor de la Iglesia, el otro en favor del Estado» ${ }^{83}$. En 1932 Peterson creía que el protestantismo estaba abocado a su disolución en «una mística secularizada»:

«[...] para comprender la evolución del concepto de iglesia y teología del neoprotestantismo hay que prestar atención al intento cumplido por desarrollar desde otros supuestos el carácter público de iglesia y teología amenazado por parte del Estado. La primera senda [...]. El segundo sendero, el intento de salvar la experiencia mística puesta en peligro por la pérdida del dogma, desembocó y naufragó en el sentimiento. Es el sendero que lleva al espiritualismo y a una mística secularizada. "El absolutismo sólo prende en el terreno de un sentimiento vivo", escribe Harnack en la misma carta. El tercer sendero [...]» ${ }^{84}$.

El esfuerzo de Peterson se centró, como muestra el epílogo que Peterson puso a la publicación (Bonn 1-VII-1928) de su epistolario con Harnack en los primeros días del verano de 1928, al que pertenece la amplia cita anterior, en fundamentar ese carácter público de la Iglesia y de la teología. Fundamentar para Peterson quería decir poder razonar públicamente la fe a partir de la reflexión teológica y vincular las comunidades a la Iglesia. Como vemos, se trata de cuestiones mayores.

\subsection{Peterson: cómo hacer FRente teológicAmente a desafíos políticos}

El monoteísmo como problema político (Der Monotheismus als politisches Problem, 1935) fue recibido por Schmitt como «un asalto inesperado del aliado y del amigo» ${ }^{85}$. Peterson, integrado de forma pública como miembro de la Iglesia católica romana, a diferencia del propio Schmitt o de Barion, ambos católicos, no entró en el partido nazi, escribió su ensayo para distanciarse de aquella gran porción de cristianos luteranos (Deutsche Christen) y reaccionó ante el riesgo real de sacralización de

82 Villacañas, 149.

83 Ibid., cita de Löwith, 111.

${ }^{84}$ Erik Peterson. "Epistolario con Adolfo Harnack. Epílogo". En Tratados teológicos, 155, al que se remite Villacañas, 149.

85 Villacañas, 150. 
la autoridad política a través de la confesionalización que reforzaba la sacralidad del orden político ${ }^{86}$. Para Peterson, que desde 1930 había sido recibido en la Iglesia católica, ésta significaba un freno ante la pretensión de sometimiento del orden religioso al orden político. Para Peterson, la coincidencia cronológica entre Cristo y Augusto era accidental y tan sólo más tarde existió un proceso de trasferencia del brillo (Glanz) y prestigio $(\mathrm{Ruhm})$ desde la religión al imperio, con lo que Orígenes argumentó que la pax augusta era la necesaria preparación para el mensaje evangélico y Eusebio de Cesarea, un publicista teológico-político, defendió que el césar cristianizado era un correlato de Cristo romanizado.

Peterson hizo otra lectura. Frente al evangelio de Mateo, destacó que Lucas hacía venir a unos reyes orientales, antirromanos y rebeldes, para adorar al Niño, con lo que quería diferenciar y resaltar, frente a la teología política romana y al dualismo maniqueo oriental, rebelde, antipolítico y gnóstico, la propuesta católica trinitaria. Schmitt, que creía que el Concilio Vaticano II se había deslizado "por la senda del liberalismo protestante», pensaba algo parecido de Peterson: «en el fondo seguía siendo un luterano espiritualista y por eso rechazaba toda teología política y toda implicación de la religión con el poder de este mundo» ${ }^{87}$.

Según Jean Daniélou, en el mejor escrito de Peterson, El libro de los ángeles (1935), éste expuso como tesis fundamental el entrecruzamiento entre liturgia, mística y política para afirmar la imposibilidad cristiana radical de fundamentar cualquier teocracia. Para el teólogo alemán convertido al catolicismo, la fe trinitaria introduce una diferencia en el ámbito de su recepción política que crea una diferencia entre el monoteísmo cristiano y el judíi ${ }^{88}$, pues «todas las acciones cultuales de la Iglesia habrían de entenderse bien como una participación de los ángeles en el culto terrestre o, al revés, todo el culto terrestre de la Iglesia sería una participación en el culto que los ángeles tributan a Dios en el cielo» ${ }^{89}$;

\footnotetext{
86 Villacañas, 150-151.

87 Villacañas, 153.

88 Gabino Uríbarri. "Erik Peterson: Teología y Escatología”. En El monoteísmo como problema político, 9. Madrid: Trotta, 1999. En relación con este tema, del mismo autor: "El nuevo eón irrumpe en el antiguo. La concepción del tiempo escatológico de Erik Peterson". Miscelánea Comillas 58 (2000): 333-357; y "La reserva escatológica: un concepto originario de Erik Peterson (1890-1960)”. Estudios Eclesiásticos 78 (2003): 29-105.

${ }^{89}$ Uríbarri, “Erik Peterson”, 22 y 42, nota 41.
} 
parece claro que para Peterson «ninguna polis terrena» puede pretender identificarse «con la ciudad de Dios ${ }^{90}$. En la ciudad de Jerusalén, transformada escatológicamente (Transzendierung), los ciudadanos cristianos pasaron a formar parte de la Jerusalén celeste, que era a un tiempo polis y templo. Para Peterson, «el culto cristiano tiene una relación originaria con la esfera política» ${ }^{91}$. Para él la Iglesia es más que una simple congregación sociológica de fieles, pues participa en el culto de la polis celeste.

Der Monotheismus era en la intención de Peterson «un escrito de controversia» frente al catolicismo favorable al nazismo, como el mismo reconoció en una carta sin fecha a Friedrich Dessauer, encontrada casualmente por Nichtweiss: «La intención de mi libro era asestarle un golpe a la Reichstheologie» ${ }^{92}$. Ésta, un movimiento católico paralelo al protestante de los Deutsche Christen, subrayaba la continuidad entre el Sacro Imperio romano germánico y el Tercer Reich, por lo que la Ilustración o la República de Weimar eran percibidas como un accidente en esa continuidad anclada en un monoteísmo pagano.

Para Peterson, la escatología cristiana, en virtud de la «reserva escatológica» (eschatologischer Vorbehalt), no permitía considerar la irrupción en una región de la historia de un Dios trascendente analógicamente concebido. Desde su interpretación agustiniana del Imperio romano, Peterson combatía la correlación entre un Dios único y un único Führer defendida por la Reichstheologie y, frente a un Eusebio de Cesarea, seguía a Gregorio Nacianceno y negaba la posibilidad de analogía entre la monarquía trinitaria divina y cualquier realidad creada. También en esto Peterson se mostraba contrario a una interpretación histórica del Sacro Imperio romano germánico que permitía que para la Reichstheologie el Reich fuera «una secularización del Reino de Dios» ${ }^{93}$. Peterson defendía la eschatologischer Vorbehalt, es decir, era contrario a la desescatologización del reino.

\footnotetext{
90 Uríbarri, “Erik Peterson”, 22.

91 Según la traducción de Uríbarri. "Erik Peterson”, 23. En la traducción de El libro de los ángeles (1935) hecha por Agustín Andreu se lee: «De nuevo encontramos una confirmación de nuestra tesis acerca de la referencia radical del culto cristiano a la esfera política» (Peterson, Tratados teológicos, 176).

${ }_{92}$ Cf. Barbara Nichtweiss. Erik Peterson. Neue Sicht auf Leben und Werk. 2. ${ }^{\text {a }}$ ed. Friburgo: Herder, 1994.

93 Uríbarri, "Erik Peterson", 32.
} 
Para Peterson la teología política no es parte de la teología cristiana, sino del pensamiento político, mientras que Schmitt entiende la teología política (Politische Theologie) desde «la identidad estructural entre los conceptos teológicos y la argumentación jurídica». Esto hace que la «incompatibilidad de fondo» entre ambos, a juicio de Uríbarri ${ }^{94}$ sea más fuerte «de lo que a simple vista parece», pues sus diferencias no se limitan a «su interpretación del valor teológico del Imperio romano, [...] sino de la concepción de las relaciones entre esfera política y teología» ${ }^{95}$. El trasvase desde la política a la teología pasa por una transformación escatológica del templo al cuerpo de Cristo, ascendido al cielo (Transzendierung). A partir de ese momento, la "gloria de Dios» ya no reside en la Jerusalén terrenal, sino en la celestial; asimismo, la "publicidad» de la Iglesia (Öffentlichkeit) dinamita y constriñe cualquier pretensión de validez de la «publicidad» política. Por las mismas razones, Peterson rechazaba la "publicidad» política de la Reichstheologie. Para el teólogo católico, las consecuencias políticas del monoteísmo cristiano no podían derivar en teología política, como sí ocurrió en el judaísmo y en el paganismo. El evangelio no podía ser usado para legitimar un orden político, ya que había una diferencia esencial de ámbitos. «No cabe ninguna componenda entre el eón antiguo y el nuevo eón», el que nace en la muerte y ascensión de Cristo ${ }^{96}$. Desde esta concepción escatológica central anclada en la eschatologischer Vorbehalt, los cristianos que forman parte del nuevo eón como criaturas nuevas, son parte de la ciudad celestial (la polis como ekklesia), en la que el cuerpo, los sacramentos y la escatología están íntimamente unidos.

El monoteísmo cristiano, sin embargo, encajaba muy bien con el Imperio romano, como su teología política imperial. En Eusebio de Cesarea, como sabemos, se podría descubrir la clave arriana del monoteísmo, «una exigencia política del Imperio $»^{97}$. La «monarquía» divina era, en cambio, un reflejo de la monarquía terrestre frente al dogma de la Trinidad: «la controversia sobre ese dogma es eminentemente política. Porque si no se podía sostener teológicamente el monoteísmo, el concepto de monarquía divina en el sentido en el que la había formulado Eusebio, entonces ya no

\footnotetext{
94 Uríbarri, "Erik Peterson”, 37.

95 Ibid.

96 Uríbarri, "Erik Peterson", 39.

97 Peterson, El monoteísmo, 92.
} 
se podía considerar a Constantino y a sus sucesores como realizadores en principio de lo que había fundado Augusto. Y entonces la unidad del imperio romano, mayoritariamente pagano todavía, estaba amenazada ${ }^{98}$.

El breve ensayo Christus als Imperator de 1936 debe ser leído desde «el trasfondo último» del Führerprinzip proclamado por los Deutschen Christen $^{99}$.

Es cierto que ya la literatura cristiana antigua llamó a Cristo imperator. Lo hizo, por ejemplo, san Agustín que escribe imperium sine fine dabit ${ }^{100}$. Cristo-emperador es el señor de un imperium que trasciende todos los imperios de este mundo y es descrito como emperador, de donde la proskýnêsis (inclinación) de los veinticuatro ancianos ( $A p$ 4,10: «los veinticuatro ancianos se postraban ante el sentado en el trono, adoraban [proskyēsousin] al que vive por los siglos y deponían sus coronas ante el trono, diciendo») ha de entenderse como un gesto político. Para Peterson «[...] los cristianos, enrolados en la militia Christi, son símbolos de la lucha por un imperio escatológico que se opone a todos los imperios de este mundo» ${ }^{101}$.

Para el dominico Yves-Marie Congar en Sainte Église ${ }^{102}$, el verdadero lugar de la Iglesia se sitúa entre la sinagoga y el Reino definitivo, por lo que, aunque el Mesías ha venido, su triunfo final aún no es visible, sino que está presente como causa de salvación. La Iglesia vive para el Reino de Cristo; entre «alfa y omega» se muestra un estatuto de vida o un "cierto régimen» intermedio entre la sinagoga y el Reino, a partir del cual se comprende mejor el verdadero «lugar teológico» de la categoría «pueblo

98 Peterson, El monoteísmo, 92.

99 «El Führerprinzip fue propugnado por el nacionalsocialismo y los Deutsche Christen. No me cabe duda de que es el trasfondo último desde donde hay que leer el Christus als Imperator (1936) (Cristo como emperador) de E. Peterson», afirma Uríbarri, "Erik Peterson", 45, nota 66, quien en las notas 64 y 65 remite a las monografías de Héctor Vall. Iglesias e ideología nazi. El Sínodo de Barmen (1934). Salamanca: Sígueme 1976; y de Klaus Breuning. Die Vision des Reiches. Deutscher Katholizismus zwischen Demokratie und Diktatur (1929-1934). Múnich: Max Hueber, 1969.

${ }^{100}$ De Civitate Dei, II: 22. Agustín escribe el verbo en futuro, que Virgilio decía en pasado: imperium sine fine dedi; cf. José Oroz. "Virgilio, poeta del 'Imperium"'. Helmantica 4 (1953): 251-277. Aen I, cita en p. 262.

101 Peterson, El monoteísmo, 132.

102 Yves-Marie Congar. Sainte Église. Études et approches ecclésiologiques. París: Cerf, 1963. 
de Dios ${ }^{103}$. También Peterson establece una diferencia entre la polis cívica y la polis celestial que abre un tiempo de espera llenado por la liturgia.

«Desde el punto de vista de la lógica política de un Estado pagano, era del todo consecuente que el detentador del poder político recibiera también los honores religiosos. En la medida en que la auctoritas pasó al princeps — y con ello, en definitiva, fue suprimida-, hubo de recaer todo el peso sobre la potestas, y de ese modo el culto religioso a los dioses del Estado desembocó en el culto al césar. El culto a los antiguos dioses del Estado pudo ser tolerante, pero el culto al césar tuvo que ser necesariamente intolerante. [...] En ese mundo [...] es preciso que el rey del eón venidero tenga algo de emperador. Si el Reino de Dios fuera exclusivamente sobrenatural, eso no sería posible; pero "si se hace violencia al Reino de Dios" [...] es posible que se anticipe la presencialización escatológica de Cristo en los rostros de sus testigos, y que el Hijo del Hombre sea visto por analogía como emperador».

«[La Iglesia] que combate en sus mártires, ve a Cristo como emperador para vencer a este mundo en que los judíos no tienen rey y los paganos sólo tienen un césar, y para esperar de ese modo al rey del mundo futuro» ${ }^{104}$.

Peterson, concluye en su estudio introductorio ${ }^{105}$, entiende la relación entre ambas esferas de publicidad sin posible confusión ni mezcla, sin posible compromiso, pues como escribió Nichtweiss: «En esta concepción teológica de dos publicidades (Öffentlichkeiten), la una, representada por la Iglesia, no suprime a la otra, la publicidad política, sino que la presupone, pero limita y dinamita su validez [... ]» ${ }^{106}$. Para Peterson el monoteísmo cristiano (trinitario) no es articulable en ninguna forma de teología política ${ }^{107}$.

"La Ilustración europea redujo la fe cristiana al "monoteísmo", cuyo contenido teológico es tan problemático como sus consecuencias políticas. La actividad política del cristiano sólo es posible en el supuesto de la fe en el Dios trino» defendía Peterson en 1935 ${ }^{108}$. El cristianismo,

103 José Ignacio Aparisi Laporta. Elección, vocación y misión del «hombre cristiano» en el marco del Reino de Dios, según el cardenal Yves Congar. Pamplona: Universidad de Navarra, 2009, 109 y 113-114.

104 Peterson, El monoteísmo, 132-133 y 135.

105 Uríbarri, "Erik Peterson", 38.

106 Cf. Nichtweiss, 752.

107 Uríbarri, "Erik Peterson", 38.

108 Peterson, Tratados teológicos, 27. Id. El monoteísmo, 50. 
entendido como monoteísmo, significaba un refuerzo de unidad para el imperio romano, como supo ver Eusebio de Cesarea ${ }^{109}$ y siguiendo esta misma línea argumental, Peterson destacaba que, en las Constituciones apostólicas, un escrito filoarriano de origen sirio del siglo IV atribuido a Julián el Arriano, «se descubría sin tapujos», dice Peterson, «el sentido político último del arrianismo. El monoteísmo es una exigencia política, una pieza del imperio ${ }^{110}$. Inspirado en la profecía de Daniel $(2,34)$, fuera quien fuera, el autor de las Constituciones presentaba a Cristo "como una gran montaña que llena la tierra y hace polvo la poliarquía política de poderes locales y el politeísmo de los impíos, predicando al Dios único e instaurando la única soberanía de los romanos» ${ }^{111}$. La monarquía divina es así un reflejo de monarquía terrestre, del imperio. Pero esta afirmación, según Peterson, entraba en colisión con el dogma de la Trinidad:

«[...] la controversia sobre ese dogma es eminentemente política. Porque si no se podía sostener teológicamente el monoteísmo, el concepto de monarquía divina en el sentido en el que la había formulado Eusebio, entonces ya no se podía considerar a Constantino y a sus sucesores como realizadores en principio de lo que había fundado Augusto. Y entonces la unidad del imperio romano, mayoritariamente pagano todavía, estaba amenazada» ${ }^{112}$.

Para Peterson, la doctrina trinitaria ortodoxa, en cuanto «rebelde» ante el poder imperial establecido, "amenazaba en verdad la teología política del imperio romano» ${ }^{113}$. Después de las controversias arrianas y trinitarias, la expresión «monarquía divina», dejó de tener un alcance teológico-político. Así, Gregorio Nacianceno afirmaba en su Discurso teológico que las «doctrinas sobre Dios se resumían en tres: la anarquía, la poliarquía y la monarquía» ${ }^{114}$. Frente a la confusión y el alboroto de las dos primeras, el obispo constantinopolitano del siglo IV subrayaba que los cristianos profesaban no una monarquía unipersonal que entrañaba un germen de disensión, sino la monarquía del Dios trino. De esta forma,

\footnotetext{
109 Peterson, Tratados, 59. Peterson, El monoteísmo, 91.

110 Peterson, Tratados, 66. Peterson, El monoteísmo, 92.

111 Peterson, Tratados, 60. Peterson, El monoteísmo, 92.

112 Peterson, Tratados, 60. Peterson, El monoteísmo, 92.

113 Peterson, Tratados, 60. Peterson, El monoteísmo, 93.

114 Gregorio di Nazianzo (C. Moreschini, ed.). Tutte le orazioni. Milán: Bompiani 2000. Citado por Giorgio Agamben. El Reino y la Gloria. Por una genealogía teológica de la economía y del gobierno. Homo sacer. II-2. Valencia: Pre-textos, 2008, 28.
} 
según Peterson, los Padres griegos cobraban conciencia de lo que diferenciaba al cristianismo y su concepción de la monarquía trinitaria del estricto monoteísmo judaico (y gentil). "Con estas consideraciones queda liquidado teológicamente el monoteísmo como problema político» ${ }^{115}$.

San Agustín realizó en la Iglesia latina una labor parecida a la de los Padres griegos, para la liquidación teológica del monoteísmo político, pues criticó la concepción de la pax augusta como base de una dudosa teología. El Obispo de Hipona recordaba inoportunamente que con Augusto murieron muchos destacados ciudadanos, entre ellos Cicerón: "Nam et ipse Augustus cum multis gessit bella civilia et in eis etiam multi clarissimi viri perierunt, inter quos et Cicero» ${ }^{116}$. Si Eusebio, Ambrosio y otros habían visto cumplido en la pax romana el anuncio del salmo y lo habían aplicado a Augusto, Auferens bella usque ad fines terrae (Salmo 45-46,10), Agustín, sabiendo que afirmaba algo opuesto, anotó que la historia no había llegado a su fin, que seguía habiendo guerras y que el trigo continuaba mezclado con la cizaña.

Como conclusión de esta presentación, merece la pena transcribir la mayor parte del final del ensayo de Peterson:

«El monoteísmo como problema político surgió de la elaboración helenística de la fe judía en Dios. El concepto de la monarquía divina, en cuanto se amalgamó con el principio monárquico de la filosofía griega, cobró para el judaísmo la función de un slogan político-teológico. [...] ese propagandístico concepto político-teológico [monoteísmo] choca después con una concepción pagana de la teología política, según la cual el monarca divino reina, pero han de gobernar los dioses nacionales. Los cristianos, para poderse oponer a esa teología pagana cortada a la medida del imperio romano, respondieron que los dioses nacionales no pueden gobernar porque el imperio romano significa la liquidación del pluralismo nacional. En este sentido se explicó luego la Pax Augusta como cumplimiento de las profecías escatológicas del Antiguo Testamento. Claro que la doctrina de la monarquía divina hubo de tropezar con el dogma trinitario, y la interpretación de la Pax Augusta con la escatología cristiana, y así no sólo se acabó teológicamente con el monoteísmo como problema político y se liberó a la fe cristiana del encadenamiento al imperio romano, sino que se llevó a cabo la ruptura radical con una "teología política" que hacía degenerar al Evangelio en instrumento de justificación de una situación política. [...] el Evangelio del Dios trino cae

115 Peterson, Tratados, 61. Peterson, El monoteísmo, 93.

116 De Civitate Dei, III: 30. 
más allá del judaísmo y el paganismo, y el misterio de la trinidad es un misterio de la misma divinidad, que no de la criatura. Así como la paz que busca el cristiano es una paz que no garantiza ningún césar, porque esa paz es un don de Aquél que está "sobre toda razón”»117.

\subsection{Dos nOtas}

A continuación, introduzco dos breves notas que tan sólo pretenden dar noticia de una problemática relacionada con este trabajo, sin posibilidad de desarrollarla en este momento.

\subsubsection{El poder que frena al poder (katéchon)}

Massimo Cacciari ${ }^{118}$ anuncia su "divergente acuerdo» con Schmitt. Admite que muchas ideas y muchos símbolos escatológico-políticos han secularizado sus contenidos, olvidándose su origen religioso, pero se plantea tres cuestiones: ¿con qué sistema político puede lograr un compromiso el paradójico monoteísmo cristiano?, ¿con la forma-imperio o con un poder que frena, contiene, administra y distribuye, o es posible lograr que ambas se mezclen?

Desde este planteamiento aparece una nueva perspectiva que complica más que aclara la contraposición entre mesianismos pro-nómico y anti-nómico, a que me he referido antes. A partir de la exégesis, la más reciente o la consagrada, no es fácil establecer el contenido del concepto katékhon que sólo aparece una vez en los escritos neotestamentarios, es un escrito pseudoepigráfico, no propiamente paulino.

No obstante, para enfatizar el relieve de este "freno», Cacciari se remonta tan sólo a textos patrísticos desde Ireneo de Lyon hasta Casiodoro, con algún otro autor de los siglos X, XI y XII, además de aportar un texto de Calvino ${ }^{119}$. A partir de 2Tes 2,6-7 estudia la figura del katéchon. Éste es alguien —o algo, pues en el versículo sexto es presentado en género masculino como «ho katéchon» y en el siguiente en neutro como

\footnotetext{
117 Peterson, Tratados, 61-62. Peterson, El monoteísmo, 94-95.

118 Massimo Cacciari. Il potere che frena. Saggio di teologia política. Milán: Adelphi, 2013.

119 Cacciari, 139-211.
} 
«to katéchon»- que retiene, frena o retrasa la llegada del Anticristo. El (o lo) katéchon debe desvelarse o ser desvelado para que aparezca el Anticristo antes del día del Señor. Según Cacciari, bastantes decisiones políticas de nuestra civilización han girado en torno a esta pregunta y autores como Agustín, Dante o Dostoievski respondieron dramáticamente a la cuestión.

Cacciari vuelve a tratar, de otra manera, sobre el aspecto central que Carl Schmitt puso en el debate contemporáneo: la relación entre teología y política y entra en el análisis de la cuestión de la secularización en la cristiandad occidental, preguntándose si se trata de la trasformación de las ideas «religiosas» en clave inmanentista o la propia secularización presupone y realiza principios esenciales contenidos en la revelación. Según Cacciari, la expresión teología política ${ }^{120}$ no puede limitarse al influjo de las ideas teológicas en las formas de soberanía mundana, aceptando partir de un presupuesto de separación de ambos órdenes, sino que también debe partir de la orientación política inmanente que está en la base de la elaboración teológica. Pablo o su discípulo, el autor de la carta segunda a los Tesalonicenses, avisa según Cacciari de que el Señor no vendrá antes de que se cumpla lo que debe hacer su adversario (anti-keimenós). La apostasía, el mysterium iniquitatis, conducirá al misterio de la epifanía. En el entreacto, el impío fingirá ser Dios y exigirá ser honrado como tal. La verdad ya está decidida y no hay novedad que descubrir, pero el día del Señor deberá ser esperado, espera que ocurrirá a través de la devastación, espera en que sobrevendrá un último asalto que hay que afrontar con la firmeza de los mártires. Cuando no queden más que el Adversario y el Señor, vendrá Éste a condenar a todos los que no hayan creído en Él.

\subsubsection{Paradigmas teológico-políticos}

También Agamben ofrece alguna claridad posterior para entender el conflicto de interpretaciones de los años veinte y treinta del siglo pasado entre Schmitt y Peterson. A partir de una de las obras que forman parte de su proyecto, El Reino y la Gloria, podemos construir o, como dice este autor, reconstruir la genealogía de los paradigmas de la teología cristiana.

120 Cacciari, 11-12. 
Creo que esta reconstrucción será útil a nuestro intento de presentar el estado actual de la cuestión de la teología política ${ }^{121}$.

El autor plantea la existencia de dos paradigmas, cada uno de ellos contra-distinto del otro. La claridad esquemática es de gran ayuda. Su punto de partida es la oposición entre Gobierno y Reino, entre oikonomía y gloria, entre "poder como gobierno y gestión eficaz y poder como realeza ceremonial y litúrgica», lo que Peterson atribuye a la gloria (Öffentlichkeit). Como es sabido, la palabra griega dóxa significa tanto gloria (divina) como opinión pública, idea, ilusión o apariencia, fama o consenso glorificante, esplendor o majestad. Podemos «descubrir en la relación entre oikonomia y gloria [...] la estructura última de la máquina gubernamental de Occidente» ${ }^{122}$. Con cierto tono irónico avisa Agamben que Habermas y otros «teóricos "democráticos" y laicos de la acción comunicativa corren el riesgo de acercarse a los pensadores conservadores de la aclamación como Schmitt y Peterson» ${ }^{123}$.

A partir de la consideración anterior, Agamben llama nuestra atención sobre la recuperación del «aspecto aclamativo y doxológico del poder [que] parecía haber desaparecido con la modernidad» ${ }^{124}$. El trono vacío es el símbolo por excelencia de la gloria y la atribución del trono (hetoimasia tou thrónou) es la forma de preparar el juicio final. Agamben, «heredero intelectual» de Schmitt ${ }^{125}$, subraya que «la estrategia de Schmitt es, en cierto modo, inversa a la de Weber», pues mientras para el filósofo protestante, la secularización forma parte del decreciente des-encantamiento y des-teologización del mundo moderno, para el jurista católico lo que aquélla muestra es justamente que la teología sigue actuando de manera eminente en la modernidad y existe una relación estratégica entre ambas, teología y modernidad, «que remite los conceptos políticos a su origen teológico».

\footnotetext{
121 Agamben, 17.

122 Agamben, 14.

123 Agamben, 14-15. 276-279. (texto citado, ibid., 278).

124 Ibid.

125 José Luis Villacañas. Teología política imperial y comunidad de salvación cristiana. Una genealogía de la división de poderes. Madrid: Trotta, 2016, 10.
} 


\section{CUADRO. DOS PARADIGMAS DE LA TEOLOGÍA CRISTIANA}

\begin{tabular}{|l|l|l|l|}
\hline Paradigma & \multicolumn{1}{|c|}{ Origen o fundamento } & \multicolumn{1}{|c|}{ Resultado } & \multicolumn{1}{c|}{ Desarrollos } \\
\hline $\begin{array}{l}\text { TEOlogía } \\
\text { POlítica }\end{array}$ & $\begin{array}{l}\text { El poder soberano } \\
\text { trascendente se funda } \\
\text { en un Dios único } \\
\text { trascendente }\end{array}$ & $\begin{array}{l}\text { Monoteísmo } \\
\text { político }\end{array}$ & $\begin{array}{l}\text { Base de filosofía } \\
\text { política moderna } \\
\text { y de la teoría de la } \\
\text { soberanía }\end{array}$ \\
\hline $\begin{array}{l}\text { TEOLOGÍa } \\
\text { ECONÓmica }\end{array}$ & $\begin{array}{l}\text { La trascendencia } \\
\text { es sustituida por la } \\
\text { inmanencia }\end{array}$ & Inmanentismo & $\begin{array}{l}\text { Base de la biopolítica } \\
\text { moderna como triunfo } \\
\text { de la economía y del } \\
\text { gobierno }\end{array}$ \\
\hline
\end{tabular}

Fuente: Giorgio Agamben. Op. cit., 13-30. Elaboración propia

\section{MARITAIN: LA AMBIGÜEDAD ESENCIAL DEL MUNDO Y SU HIS- TORIA}

A finales de los años 1920, Jacques Maritain había reflexionado sobre el poder indirecto del papa en relación al poder político y había asumido las teorías, ampliamente aceptadas entre los católicos de su época, que ya eran las defendidas por los jesuitas de finales del siglo XVI y principios del siglo XVII, entre otros, alguno tan destacado como Francisco Suárez o Roberto Belarmino.

Primauté du spirituel de Jacques Maritain selló definitivamente en $1927^{126}$ su ruptura con el movimiento paganizante, aunque utilitaristamente católico-romano, de Action française, que Pío XI había rechazado y condenado en la Carta "Nous avons lu" al cardenal Andrieu, arzobispo de Burdeos, de 5-9-1926. Unas semanas después, el papa el 5 de enero de 1927 recordaba el decreto del Santo oficio sobre «la grave question de l'Action Française» ${ }^{127}$. En ella el papa decía a Andrieu que tenía cierto derecho a la primicia —en realidad le adelantaba la noticia, quizá porque no acababa de fiarse de que Andrieu, como una inmensa mayoría de

126 Maritain, Jacques, y Raïssa Maritain, Primauté du spirituel. En Euvres complètes, 3:783-988. Friburgo (Suiza) - París: Universitaires - Saint-Paul, 1984.

127 Cf. Documentos políticos, 518-523. En la introducción y en las notas, a las que remitimos, hay abundante información sobre el contexto y sobre otros documentos. El texto de la Carta autógrafa de Pío XI en AAS 19 (1927): 5-8. El decreto del Santo oficio en AAS 18 (1926): 529-530. 
católicos franceses, no simpatizase en el fondo con la Action françaisepuesto que el arzobispo bordelés había sido el primero en suscitar el tema entre el episcopado francés.

«Le décret a une importance assez grande, ne serait-ce que par ce qu'il détruit d'un seul coup la légende qu'on a tissue, en bonne foi comme Nous aimons à le croire, autour de Notre vénéré Prédécesseur Pie X. de s. m.» ${ }^{128}$.

El papa Ratti declaraba que actuaba en continuidad con lo que había hecho Pío X: «Nous avons fini là ou Pie X a commencé». El papa no quería que nadie le atribuyese oposición a su predecesor:

«[... il Nous était très pénible de voir opposer (comme on l'a si souvent fait plus ou moins ouvertement) le nom et la prétendue conduite de Notre vénéré Prédécesseur à Notre nom et à Notre conduite vis-à-vis de l'Action Française» ${ }^{129}$.

Tal oposición, según Pío XI, o eso quiso hacer creer, no respondía a la verdad. Como Schmitt en 1969, también el papa Ratti quiso destruir otra légende. En el decreto de la Congregación del Santo oficio de 29-XII-1926 se condenaba a Charles Maurras y su periódico l'Action française, haciendo referencia a las sesiones de la Congregación del 15-1-1914, 26-1-1914 y 29-1-1914, anteriores a la gran guerra, pero también a la sesión de aquel mismo día, 29-12-1926, en la que se había decidido incluir en el Index librorum prohibitorum varias obras de Maurras y de Léon Daudet, además de prohibir el citado periódico bimensual Action Française: «haec tamen opera esse prohibita». El mismo decreto explicaba que, a pesar de que hacía años que el procedimiento había comenzado, las circunstancias de la guerra no habían permitido que éste fuera publicado:

«Quibus auditis Sanctitas Sua declaravit hoc tempus nondum venisse, cum, bello adhuc perdurante, passiones politicae aequum iudicium de tali actu Sanctae Sedis haud admittant» ${ }^{130}$.

Por su parte, el 14-IV-1915 el papa Della Chiesa en la encíclica inaugural de su pontificado — Summus Pontifex — ya se había interrogado

\footnotetext{
128 AAS 19 (1927).

129 Ibid.

130 Cf. $A A S 18$ (1926): 529.
} 
sobre l'Action Française ${ }^{131}$ y pidió la inclusión de los nombres de Maurras y Daudet en el "Index".

En su obra fundamental, Humanisme intégral, Maritain ${ }^{132}$ trató de esta cuestión en dos momentos. Uno para subrayar la con/sistencia y ex/sistencia del Reino de Dios «dans» ${ }^{133}$ l'histoire y otro para referirse al «problème du Royaume de Dieu» concluyendo con una reflexión sobre «l'ambivalence du monde» ${ }^{134}$. Para Maritain éste es el principal problema: ¿qué papel hace falta reconocer a lo espiritual y qué papel a lo temporal en la relación al Reino? El filósofo de Meudon distinguía tres problemas y proponía una solución. En esa explicación subrayaba la diferencia de sentido que ya hemos indicado entre théologie politique y politische Theologie y a continuación citaba la obra de Aloys Dempf ${ }^{135}$.

Para Maritain, la teología política es una parte de la reflexión teológica a la luz de los principios revelados consagrada a un objeto profano y temporal como es la política, una parte de toda teología práctica. La concepción alemana (politische Theologie) tiene un objeto en sí mismo «sagrado» (heilig), por lo que Maritain se refiere a Carl Schmitt ${ }^{136}$ como quien sostuvo que "grandes ideas políticas y jurídicas modernas» transponen temas esencialmente teológicos.

131 Diferencio tipográficamente entre Action française en redonda (movimiento) y Action française en cursiva (periódico).

132 Humanisme intégral. 4. a ed. París: Aubier, 2000 (cf. Oeuvres complétes, 6:291-634).

133 La preposición DANS/dans en versales en el encabezado del texto y en cursivas en el índice se señala tipográficamente tanto en la cuarta edición de París 2000, 63 y 314, como en Oeuvres complétes, 6:356 y 6:1308.

134 Cf. Jacques Maritain. Humanisme intégral. 4. a ed. París: Aubier, 2000, 63-68 y 107-119 (cf. Oeuvres complétes, 6:356-362 y 6:405-418).

135 Aloys Dempf. Sacrum Imperium. Sacrum Imperium. Geschichte und Staatsphilosophie des Mittelalters und der Politischen Renaissance. Darmstadt: Wissenschaftliche Buchgesellschaft, 1962.

136 Cf. Maritain, Humanisme intégral, 108, o Oeuvres complétes 6:406 dicen de Schmitt «qui fut un des inspirateurs et des conseillers intellectuels du régime nazi». En la versión española de Alfredo Mendizábal publicada por Ercilla en Chile en 1941, hecha sobre la primera edición de 1936, se dice de Schmitt en tiempo verbal presente que es «uno de los inspiradores y consejeros intelectuales del movimiento nazi»; ésa es la misma redacción que aparece en Jacques Maritain. Humanismo integral. Problemas temporales y espirituales de una nueva cristiandad. Buenos Aires: Carlos Lohlé, 1963, 82, en traducción también de Alfredo Mendizábal con pequeñas variaciones, pero siempre en tiempo presente: «uno de los inspiradores y de los consejeros intelectuales del nuevo régimen». 
Treinta y cinco años más tarde, tras una dura guerra y una posguerra mundiales, el teólogo peruano Gustavo Gutiérrez dedicó un capítulo de Teología de la liberación a exponer la crítica de la posición de Maritain ${ }^{137}$. Gutiérrez se refirió a la conocida como «distinción de planos» propuesta por Maritain en 1935 e integrada en Humanisme intégral, que el primero interpretaba como consecuencia del influjo del "agustinismo político» en Maritain. Citando a Arquillière y a de Lubac ${ }^{138}$, Gutiérrez concluía «el proyecto por el Reino de Dios no deja lugar a un proyecto histórico profano", dada la estrecha unidad de fe y vida social y al hecho equívoco de que la Iglesia tiende a proyectar «el poder sobre la salvación» en el poder político, pues según el teólogo peruano Maritain reflexionaba "con categorías que no logran desprenderse completamente [...] de la mentalidad tradicional $»^{139}$. "Al sostener que la gracia no suprime ni reemplaza la naturaleza, sino que la perfecciona, Tomás de Aquino abre las posibilidades de una acción política más autónoma y desinteresada» y aunque reconoce que en Maritain «la visión de la Iglesia como poder frente al mundo se matiza fuertemente» también le sigue atribuyendo "un cierto narcisismo eclesiástico» que busca "a través de la creación de una sociedad justa y democrática, condiciones favorables a la acción de la Iglesia en el mundo» para lo que necesita «una sociedad inspirada en principios cristianos $»^{140}$, tras lo que concluye que «no se trató sino de un tímido, y en el fondo, ambiguo ensayo» en que «se mezclaba una cierta nostalgia del pasado con una mentalidad modernizante». Tras la posición crítica de Gutiérrez podemos entrever su reacción ante el debate, no sólo francés, entre Congar, Liégé, Rahner, Chavasse, Philips, Baumgartner y otros en los años anteriores al concilio y el relacionado con la misión y la experiencia de los más avanzados movimientos de apostolado seglar en América latina. A juicio de Gutiérrez ${ }^{141}$ el esquema de la distinción de planos tuvo «la ventaja de ser claro y de lograr un difícil equilibrio entre la

137 Gustavo Gutiérrez Merino. Teología de la liberación. Perspectivas. 7. ed. Salamanca: Sígueme, 1975. El autor dedica a esta cuestión todo el capítulo II-4 (Planteamiento del problema. Diferentes respuestas, 83-92).

138 Henri-Xavier Arquillière. L'augustinisme politique: essai sur la formation des théories politiques au Moyen-Age, París: Vrin 1934. Henri de Lubac. Augustinisme et théologie moderne. París: Aubier, 1965.

139 Gutiérrez Merino, 86.

140 Gutiérrez Merino, 87.

141 Gutiérrez Merino, 92. 
unidad del plan de medios y la distinción Iglesia-mundo». Su posteridad es cuestión que queda fuera de este artículo.

\section{CONCLUSIÓN}

En el recorrido realizado, hemos visto cómo el debate sobre la teología del Reino ${ }^{142}$, la aceleración de su llegada o la reconstitución de una forma política inexistente, se entrecruza con el surgimiento de la reflexión judía sobre el mesianismo cuyo momento cumbre fue La estrella de la redención (1921) de F. Rosenzweig. En 1933 Erik Peterson denominó a Israel «sólido olivo» y consecuentemente añadió que «el judío que no cree en Cristo sigue perteneciendo al noble olivo de Dios» ${ }^{143}$. Jacques Maritain prologaba dos años más tarde la traducción francesa de El misterio de los judios y de los gentiles en la Iglesia de Peterson, publicada en la colección "Courrier des îles" de Desclée de Brouwer de París. Quizá Peterson, de quien el teólogo Joseph Ratzinger, ya papa, dijo: «Come ho detto, lui era qui e là [nella teologia cattolica e in quella evangelica] uno straniero» ${ }^{144}$, estaba en un «qui e là», un no-lugar, el lugar indicado para entender que, siendo la revelación trinitaria la plenitud, aquélla estaba condicionada para llegar a serlo por la aceptación del «noble olivo», del «sólido olivo de Israel». Era otra forma de expresar el «ya pero todavía no». Peterson como otros pensadores de aquellas décadas fueron, tuvieron que ser, peregrinos, es decir, en algún momento «extranjeros». El papel del creyente judío, como "testigo de lo absoluto», y el que ejercen todos, creyentes y no practicantes, con su mera existencia, es la marca de la diferencia que nos previene contra cualquier tentación de absolutizar toda religión, incluso la pretensión de un carácter absoluto del cristianismo. Si Cristo — su carne, su sangre (Heb 10,19) — es el mediador, ninguna mediación, ni siquiera

\footnotetext{
142 Jean Richard. "Le Royaume de Dieu dans la théologie contemporaine". Laval théologique et philosophique 38 (1982): 153-171.

143 Peterson, Tratados, 137-138, comentando Rom 11,17-21.

144 Benedicto XVI. Discorso ai partecipanti al Simposio internazionale su Erik Peterson [la presenza teológica di un outsider] (25-X-2010) (www.vatican.va, consulta 262-2011). Peterson se consideraba a sí mismo un "pároikos», un peregrino que se hace vecino, que se acerca aun cuando sigue siendo extranjero, una instancia escatológica en el panorama teológico y eclesial, imposible de asimilar o encasillar, consideración a la que alude el papa.
} 
su Cuerpo eclesial puede pretender un carácter absoluto. Sólo somos acebuche (oleaster Rm 11,17) o rama injertada y, por ello, los cristianos no podemos pretender ser más de lo que ya somos. Participamos con los judíos «de la raíz y de la savia del olivo» (Rom 11,17), pero san Pablo advierte: «non tu radicem portas, sed radix te» (Rom 11,18). El pueblo judío, pueblo elegido, tiene la autoridad del día final que precederá a la segunda venida del Mesías, quien encontrará entonces un solo pueblo.

Un proyecto histórico de matriz cristiana como el occidental está condenado al fracaso (R. Mate), si pierde de vista la interpelación judía. El cristiano no puede renunciar al judío pues pone en liza su propio proyecto histórico. Si lo hiciese, ésa sería su «tragedia», pues identificar el Reino con alguna «estación de paso» finalmente le llevaría a quedar en «vía muerta» o a descarrilar. Esta «reserva», en el fondo otra manera de aproximarse a la eschatologischer Vorbehalt (Peterson), previene al cristiano contra toda «realidad nacional» o contra todo sistema, socioeconómico o político, como algo definitivo. El cristiano no puede reducir el contenido de su fe a un momento de la historia.

El papa Ratzinger lo expresó así:

«Preguntémonos ahora de nuevo: ¿qué podemos esperar? Y ¿qué es lo que no podemos esperar? [...] Nunca existirá en este mundo el reino del bien definitivamente consolidado. Quien promete el mundo mejor que duraría irrevocablemente para siempre, hace una falsa promesa [...]. Si hubiera estructuras que establecieran de manera definitiva una determinada — buena - condición del mundo, se negaría la libertad del hombre, y por eso, a fin de cuentas, en modo alguno serían estructuras buenas $[\ldots]{ }^{145}$.

El cristiano, al tratar de convertir el mundo, corre el peligro de tomar una etapa por la meta, por lo que, "para escapar a ese peligro necesita vitalmente apoyarse en la existencia física del pueblo judío. El Dios cristiano tiene sus raíces en el Dios de Israel» ${ }^{146}$. La subsistencia del pueblo judío como tal es la señal de que el cristiano está por el buen camino, es decir, en camino. Lo que para el judaísmo es «vida», para el cristianismo es «vía». Debemos encuadrar el interesante debate sobre el mesianismo, más filosófico que estrictamente teológico, en el proceso de larga duración de secularización del pensamiento judío y de la reacción hasídica ante

\footnotetext{
${ }^{145}$ Benedicto XVI. Carta encíclica Spe salvi (30-11-2007), n. 24 y 25.

146 Mate, XIII.
} 
la ilustración, paralelo al proceso de secularización cristiana, la teología liberal o el modernismo como penúltimos capítulos, procesos de secularización iniciados en ambos casos en el siglo XVIII.

En el periodo estudiado (1922-1939) se hizo más visible que tanto judíos como católicos tenían por delante "la esperanza del Reino» y mientras el Mesías no llegase en su primera - para los judíos-o en su segunda venida, no era posible ni deseable sacralizar ningún poder político. La fe en la Trinidad vacunaba al cristianismo contra toda veleidad de religión política. Aunque de orígenes diferentes, en esos años los debates teológicos, filosóficos y jurídicos, por una parte, y por otra con puntos de vista judíos, protestantes y católicos se superpusieron hasta confluir en uno solo. "¿introduce la fe trinitaria alguna diferencia en el ámbito de su recepción política, que contradistinga al monoteísmo cristiano del judío?» ${ }^{147}$, se preguntó Uríbarri. Creemos que sí. Como hemos pretendido mostrar, después de la pretensión fracasada de Eusebio de Cesarea, anterior a Agustín de Hipona, fue la ilustración europea la que «volvió a las andadas» para reducir la fe cristiana a un «monoteísmo», cuyo contenido teológico es tan problemático como sus consecuencias políticas. En El libro de los ángeles, Peterson expuso la tesis fundamental del entrecruzamiento entre liturgia, mística y política para afirmar la imposibilidad cristiana radical de fundamentar cualquier teocracia: «Todas las acciones cultuales de la Iglesia habrían de entenderse bien como una participación de los ángeles en el culto terrestre o, al revés, todo el culto terrestre de la Iglesia sería una participación en el culto que los ángeles tributan a Dios en el cielo» ${ }^{148}$. Dicho de otra forma, la única teología política católica posible en el tiempo es la liturgia.

Hemos realizado una revisión de la literatura científica existente sobre este tema, que nos ha permitido contemplar la continuidad y las relativas novedades que, entre otras, se van introduciendo, como la Reichstheologie, la teología dialéctica y la teología política que deriva de ella, la nueva comprensión del mesianismo. La radical novedad y la pertinente actualidad del planteamiento que hizo Jacques Maritain sobre el ideal histórico de una nueva cristiandad analógicamente concebida como ciudad secular, pluralista y «peregrinante», se percibe cada día más como algo nuevo. Aquélla no era nueva por cristiandad, ni por responder a un ideal

147 Uríbarri, "Erik Peterson”, 9.

148 Peterson, Tratados, 11. 
histórico concreto. En ese aspecto no dejaba de estar en continuidad con la formulación, también realizada desde la analogia entis, de Tomás de Aquino en el siglo XIII. La novedad estribaba precisamente en superar el planteamiento mesiánico de identidad del Reino esperado de las diferentes concepciones presentes, en la Reichstheologie o en la teología pontificia del Regnum Christi (encíclicas Ubi arcano (1922) y Quas primas (1925) de Pío XI), en superar la dialéctica barthiana de la distancia absoluta y de negación de toda posible analogía (ya sabemos que, al menos hasta el "giro a la analogía» de 1927 en expresión de von Balthasar, para Barth la analogia entis era el mismo anticristo) y de romper con la lógica de prolongación de las expectativas mesiánicas en propuestas utópicas ajenas a la realidad como pretendían el comunismo soviético, los fascismos nacionalistas o los racismos del tiempo. Ni identidad, ni negación, ni utopía, sino simple, y al mismo tiempo compleja, afirmación de una analogicidad desde la que concebir el Reino.

Como en otros lugares podremos considerar este escatológico «ayudar a dar a luz» el Reino, que es común a los diversos actores teológicos de las décadas entre 1922 y 1939, permite comprender mejor la originalidad del proyecto histórico alumbrado por Maritain, un Reino que se descubre y se da a luz mayéuticamente ${ }^{149}$.

Mucho después Carl Schmitt llamó «puntilla» indolora a la teología política a la pretensión de Erik Peterson en su Monotheismus. A Peterson y a Schmitt, autor de una Politische Theologie (1922), reeditada con alguna revisión en 1933, se refirió Maritain en las conferencias sobre «Problemas espirituales y temporales de una nueva cristiandad» pronunciadas en Santander, cuyo texto dio lugar dos años después a su ensayo Humanisme intégral (1936). La teología del Reino — «le problème du Royaume de Dieu» escribe Maritain ${ }^{150}$ — está entre los temas teológicos de las dos décadas entre 1920 y 1940.

149 Josep Maria Margenat Peralta. "El proyecto histórico del diálogo en Pablo VI". En Ciudad de los hombres, ciudad de Dios. Homenaje a Alfonso Álvarez Bolado S. I., editado por Xavier Quinzà i Lleó, y José Joaquín Alemany Briz, 335-354. Madrid: Universidad Pontificia Comillas, 1999. Andrés Torres Queiruga. La revelación de Dios en la realización del hombre. Madrid: Cristiandad, 1987. (Y la reedición renovada por el autor. Repensar la revelación. La revelación divina en la realización humana. Madrid: Trotta, 2008).

150 Jacques Maritain. Humanisme intégral. Op. cit. 107. Euvres complètes, 6: 405. 
Si, como hemos visto, las teologías del Reino, sea el Regnum Christi, sea la Reichstheologie protestante o católica, pretendían alguna forma de identificación del Reino con estructuras presentes en el momento, la discusión entre Peterson y Schmitt, a la que se asoma Maritain, representando la toma en consideración del monoteísmo político y de la concepción trinitario-litúrgica para afrontar el problema del sujeto de la soberanía, bien en una politización extrema de la teología, bien desde una despolitización escatológica de la perspectiva teológica a partir de la soberanía trinitaria, entendiendo ésta no como vaciamiento de la política sino como afirmación de la relativización de toda política.

Ambos pensamientos, el de Peterson y el de Maritain, abrieron perspectivas aún hoy valiosas para el pensamiento teológico y filosófico de principio del siglo XXI. Para nuestro tiempo sigue siendo válida, a nuestro juicio, la propuesta de Maritain, sobre el mundo y la historia como lugares de la Encarnación y, por tanto, lugares y tiempos esencialmente ambiguos. La pregunta intermedia entre la politización absoluta y la relativización de toda política sólo terrenal sigue siendo: ¿tiene el cristianismo una esperanza para este mundo?

\section{REFERENCIAS}

Adorno, Theodor W. Minima Moralia. Madrid: Taurus, 1987.

Acerbi, Antonio. La Chiesa nel tempo. Sguardi sui progetti di relazioni tra Chiesa e società civile negli ultimi cento anni. 2. ${ }^{\text {a }}$ ed. Milán: Vita e Pensiero, 1984.

Acerbi, Antonio. Chiesa e democrazia. Da Leone XIII al Vaticano II. Milán: Vita e pensiero, 1991.

Agamben, Giorgio. El Reino y la Gloria. Por una genealogía teológica de la economía y del gobierno. Homo sacer. II-2. Valencia: Pre-textos, 2008.

Aparisi Laporta, José Ignacio. Elección, vocación y misión del «hombre cristiano» en el marco del Reino de Dios, según el cardenal Yves Congar. Pamplona: Universidad de Navarra, 2009.

Arquillière, Henri-Xavier. L'augustinisme politique: essai sur la formation des théories politiques au Moyen-Age, París : Vrin 1934 y 2. ${ }^{a}$ edición. París 1955. Hay traducción al castellano. Granada: Universidad de Granada 2005. 
Barreto, Daniel. El desafío nacionalista. El pensamiento teológico-político de Franz Rosenzweig. Barcelona: Anthropos, 2018.

Barth, Karl. Carta a los Romanos. Madrid: BAC, 2002.

Benjamin, Walter. Obras. II-1. Madrid: Abada, 2007.

Bensussan, Gérard. Le temps messianique. Temps historique et temps vécu. París: Vrin, 2001.

Borghesi, Massimo. Critica della teologia política. Da Agostino a Peterson: la fine dell'era constantiniana. Bolonia: Marietti, 2018.

Breuning, Klaus. Die Vision des Reiches. Deutscher Katholizismus zwischen Demokratie und Diktatur (1929-1934). Múnich: Max Hueber 1969.

Cacciari, Massimo. Il potere che frena. Saggio di teologia politica. Milán: Adelphi, 2013.

Congar, Yves-Marie. Sainte Église. Études et approches ecclésiologiques. Paris: Cerf, 1963.

D’Angelo, Valerio. “"Ni dieux ni maître». Anarquismo y teología política”. Res Publica. Revista de Historia de las Ideas Políticas 22 (2019): 123140. DOI: https://doi.org/10.5209/RPUB.63888

Dempf, Aloïs. La filosofía cristiana del Estado en España. Madrid: Rialp, 1967.

Dempf, Aloïs. Sacrum Imperium. Geschichte und Staatsphilosophie des Mittelalters und der Politischen Renaissance. Darmstadt: Wissenschaftliche Buchgesellschaft, 1962. DOI: https://doi.org/10.1515/9783486757125

Fisichella, Rino. “Mesianismo. II. Realización mesiánica”. En Diccionario de Teología Fundamental. 3. ${ }^{\text {a }}$ ed. Madrid: San Pablo, 2010 [1990], 900-908.

Fries, Heinrich. "La revelación. Las dos formas de revelación a la luz de la sagrada escritura". En Mysterium Salutis. Manual de Teología como historia de la Salvación, dirigida por Johannes Feiner, y Magnus Löhrer, vol. 1, 228-286. Madrid: Cristiandad, 1974.

Galindo Hervás, Alfonso. "Secularización y mesianismo. El pensamiento político de Jacob Taubes". Diánoia 57, n. ${ }^{\circ} 68$ (2012): 81-111. DOI: https://doi.org/10.21898/dia.v57i68.153

Galino Carrillo, M. ${ }^{a}$ Ángeles. Los tratados de educación de príncipes. Madrid: CSIC, 1946.

Gómez Orfanel, Germán. "Carl Schmitt y el decisionismo político". En Historia de la teoría política, coordinado por Fernando Vallespín, vol. 5, 243-272. Madrid: Alianza, 1995. 
Gutiérrez Merino, Gustavo. Teología de la liberación. Perspectivas. 7. a ed. Salamanca: Sígueme, 1975.

Heim, François. La Théologie de la victoire de Constantin à Théodose. Paris: Beauchesne, 1992.

Idel, Moshe. Mesianismo y misticismo. Barcelona: Riopiedras, 1994.

Kantorowicz, Ernst H. Los dos cuerpos del rey. Un estudio de teología política medieval. Madrid: Alianza, 1985.

Koch, Traugott. "Sociedad y reino de Dios". En Fe cristiana y sociedad moderna, dirigido por Franz Böckle, Franz-Xaver Kaufmann, Karl Rahner y Bernhard Welte, vol. 28, 13-79. Madrid: SM, 1989.

Lévinas, Emmanuel. Difícil libertad y otros ensayos sobre judaísmo. 2. ${ }^{a}$ ed. Buenos Aires: Lilmod-Fineo, 2008.

Löwith, Karl. Mi vida en Alemania antes y después de 1933. Un testimonio. Madrid: La Balsa de la Medusa, 1993.

Lubac, Henri de. Augustinisme et théologie moderne. París: Aubier, 1965. Y edición en Euvres complètes, 13. París: Cerf, 2008.

Margenat Peralta, Josep Maria. El factor católico en la construcción del consenso del nuevo Estado franquista (1934-1937). Madrid: Universidad Complutense, 1991.

Margenat Peralta, Josep Maria. "El proyecto histórico del diálogo en Pablo VI". En Ciudad de los hombres, ciudad de Dios. Homenaje a Alfonso Álvarez Bolado S. I., editado por Xavier Quinzà i Lleó, y José Joaquín Alemany Briz, 335-354. Madrid: Universidad Pontificia Comillas, 1999.

Maritain, Jacques. Humanisme intégral. Problèmes temporels et spirituels d'une nouvelle chrétienté. 4. ${ }^{a}$ ed. París: Aubier, 2000.

Maritain, Jacques, y Raïssa Maritain. "Humanisme intégral”. En Euvres complètes, vol. 6, 291-634. Friburgo (Suiza) - París: Universitaires Saint-Paul, 1984.

Maritain, Jacques. Humanismo integral. Problemas temporales y espirituales de una nueva cristiandad. Buenos Aires: Carlos Lohlé, 1963.

Maritain, Jacques, y Raïssa Maritain. "Primauté du spirituel”. En Euvres complètes, vol. 3, 783-988. Friburgo (Suiza) - París: Universitaires Saint-Paul, 1984.

Mate, Manuel Reyes. "El subsuelo teológico del nacionalismo". En El desafío nacionalista, Daniel Barreto, VII-XXXI. Barcelona: Anthropos, 2018. Menozzi, Daniele. Chiesa cattolica e secolarizzazione. Turín: Einaudi, 1993. Menozzi, Daniele. Sacro Cuore. Un culto tra devozione interiore e restaurazione cristiana della società. Roma: Viella, 2002. 
Menozzi, Daniele. Chiesa e diritti umani: Legge naturale e modernità politica dalla Rivoluzione Francese ai nostri giorni. Bolonia: il Mulino, 2012.

Menozzi, Daniele. I papi e il moderno. Una lettura del cattolicesimo contemporaneo (1903-2016). Brescia: Morcelliana, 2016.

Menozzi, Daniele, y Renato Moro. Cattolicesimo e totalitarismo. Chiesa e cultura religiosa tra le due guerre mondiali. Italia, Francia e Spagna. Brescia: Morcellliana, 2004.

Muñoz, Rafael. "La mediación del Logos preexistente a la encarnación en Eusebio de Cesarea". Estudios Eclesiásticos 43 (1968): 381-414.

Nichtweiss, Barbara. Erik Peterson. Neue Sicht auf Leben und Werk. 2. ${ }^{a}$ ed. Friburgo: Herder, 1994

Oroz, José. "Virgilio, poeta del «Imperium»". Helmantica 4 (1953): 25 1-277. DOI: https://doi.org/10.36576/summa.2395

Peterson, Erik. Tratados teológicos. Madrid: Cristiandad, 1966.

Peterson, Erik. El monoteísmo como problema político. Madrid: Trotta, 1999.

Peterson, Erik. Cristo como Imperator. En El monoteísmo como problema político, 125-137. Madrid: Trotta, 1999.

Ramière, Henri. Las esperanzas de la Iglesia. Barcelona: Cristiandad, 1962.

Ramière, Henri. La soberanía social de Jesucristo o las doctrinas de Roma acerca el liberalismo en sus relaciones con el dogma cristiano y las necesidades de las sociedades modernas. Barcelona: Subirana, 1875.

Ramière, Henri. La bancarrota del liberalismo y el catolicismo liberal. Barcelona: Católica, 1876.

Ramière, Henri. La soberanía social de Cristo. Barcelona: Cristiandad, 1951. Richard, Jean. "Le Royaume de Dieu dans la théologie contemporaine". Laval théologique et philosophique 38 (1982): 153-171. DOI: https://doi. org/10.7202/705927ar

Rigaux, Beda. Les Épittres aux Thessaloniciens. París: Gabalda, 1956.

Rochais, G. "Mesianismo. I. Espera mesiánica". En Diccionario de Teología Fundamental. 3. ${ }^{a}$ ed., 884-900. Madrid: San Pablo, 2010 [1990].

Rosàs Tosas, Mar. Mesianismo en la filosofía contemporánea. De Benjamin a Derrida. Barcelona: Herder, 2016.

Rosenzweig, Franz. La estrella de la redención. 2. a ed. Salamanca: Sígueme, 2006.

Schmitt, Carl. Teología política. Madrid: Trotta, 2009.

Sureau, Denis. Una nueva teología política. (En torno a la "Radical Orthodoxy"). Granada: Nuevo Inicio, 2010. 
Taubes, Jakob. La teología política de Pablo. Madrid: Trotta, 2007.

Torres Queiruga, Andrés. La revelación de Dios en la realización del hombre. Madrid: Cristiandad, 1987.

Torres Queiruga, Andrés. Repensar la revelación. La revelación divina en la realización humana. Madrid: Trotta, 2008.

Uríbarri Bilbao, Gabino. "Erik Peterson: Teología y Escatología". En El monoteísmo como problema político, Erik Peterson, 9-46. Madrid: Trotta, 1999.

Uríbarri Bilbao, Gabino. "El nuevo eón irrumpe en el antiguo. La concepción del tiempo escatológico de Erik Peterson". Miscelánea Comillas 58 (2000): 333-357.

Uríbarri Bilbao, Gabino. "La reserva escatológica: un concepto originario de Erik Peterson (1890-1960)”. Estudios Eclesiásticos 78 (2003): 29-105.

Vall Vilardell, Héctor. Iglesias e ideología nazi. El Sínodo de Barmen (1934). Salamanca: Sígueme, 1976.

Vallin, Pierre. "Le Père Henri Ramière (1821-1884)". Bulletin de Littérature Écclesiastique 86 (1985): 24-34.

Vattimo, Gianni et alii (eds.) [s. a.]. "Messianismo": En Enciclopedia Garzanti di Filosofia. Roma, 1993.

Villacañas Berlanga, José Luis. "La leyenda de la liquidación de la teología política". En Teología política, Carl Schmitt, 135-180. Madrid: Trotta, 1999.

Villacañas Berlanga, José Luis. Teología política imperial y comunidad de salvación cristiana. Una genealogía de la división de poderes. Madrid: Trotta, 2016. 